Key Words: Plutonium, oxidation state, sediment, transport, performance assessment, composite analysis, lysimeter, X-ray fluorescence imaging, X-ray adsorption near-edge structure spectroscopy.

Retention: Permanent

\title{
Plutonium Oxidation State Transformations and Their Consequence on Plutonium Transport through Sediment During an 11-year Field Study (U)
}

\author{
Daniel I. Kaplan ${ }^{(a)}$, Deniz I. Demirkanli ${ }^{(b)}$, Martine C. Duff ${ }^{(a)}$, Robert A. Fjeld ${ }^{(b)}$, Leo \\ Gumapas $^{(\mathbf{b})}$, Fred J. Molz ${ }^{(\mathrm{b})}$, Brian A. Powell ${ }^{(\mathrm{b})}$, Steven M. Serkiz ${ }^{(\mathrm{a})}$ \\ ${ }^{\text {(a) Westinghouse Savannah River Company, }}{ }^{\text {(b) }}$ Clemson University
}

September 30, 2004

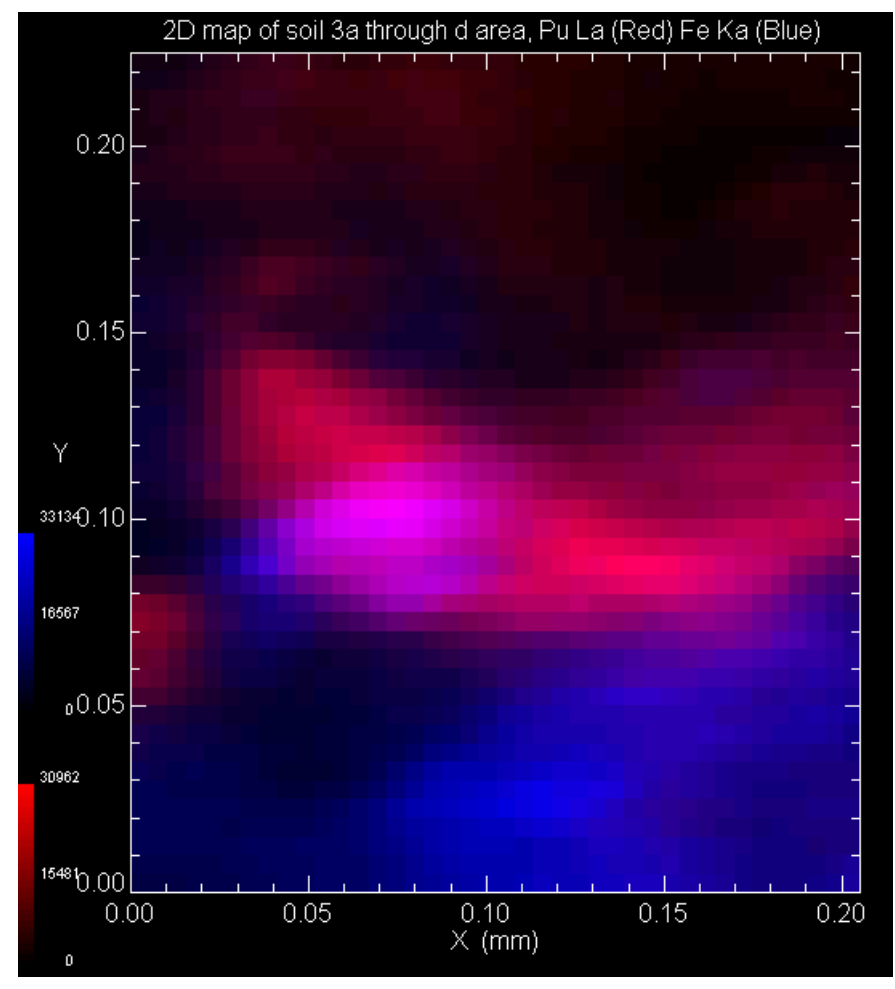

Westinghouse Savannah River Company

Savannah River Site

Aiken, SC 29808

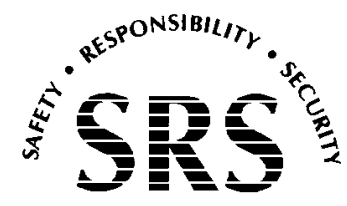

SAVANNAH RIVER SITE

Prepared for the U.S. Department of Energy Under

Contract Number DE-AC09-96SR18500 
This document was prepared in conjunction with work accomplished under Contract No. DE-AC09-96SR18500 with the U. S. Department of Energy.

\section{DISCLAIMER}

This report was prepared as an account of work sponsored by an agency of the United States Government. Neither the United States Government nor any agency thereof, nor any of their employees, makes any warranty, express or implied, or assumes any legal liability or responsibility for the accuracy, completeness, or usefulness of any information, apparatus, product or process disclosed, or represents that its use would not infringe privately owned rights. Reference herein to any specific commercial product, process or service by trade name, trademark, manufacturer, or otherwise does not necessarily constitute or imply its endorsement, recommendation, or favoring by the United States Government or any agency thereof. The views and opinions of authors expressed herein do not necessarily state or reflect those of the United States Government or any agency thereof.

This report has been reproduced directly from the best available copy.

Available for sale to the public, in paper, from: U.S. Department of Commerce, National Technical Information Service, 5285 Port Royal Road, Springfield, VA 22161, phone: (800) 553-6847, fax: (703) 605-6900

email: orders@ntis.fedworld.gov

online ordering: http://www.ntis.gov/help/index.asp

Available electronically at http://www.osti.gov/bridge

Available for a processing fee to U.S. Department of Energy and its contractors, in paper, from: U.S. Department of Energy, Office of Scientific and Technical Information, P.O. Box 62, Oak Ridge, TN 37831-0062,

phone: (865)576-8401,

fax: (865)576-5728

email: $\underline{\text { reports@ adonis.osti.gov }}$ 
Key Words: Plutonium, oxidation state, sediment, transport, performance assessments

Retention: Permanent

\section{Plutonium Oxidation State Transformations and Their Consequence on Plutonium Transport Through Sediment During an 11-year Field Study (U)}

Daniel I. Kaplan ${ }^{(a)}$, Deniz I. Demirkanli ${ }^{(b)}$, Martine C. Duff ${ }^{(a)}$, Robert A. Fjeld ${ }^{(b)}$, Leo Gumapas $^{(\mathbf{b})}$, Fred J. Molz ${ }^{(\mathbf{b})}$, Brian A. Powell ${ }^{(b)}$, Steven M. Serkiz ${ }^{(\mathbf{a})}$

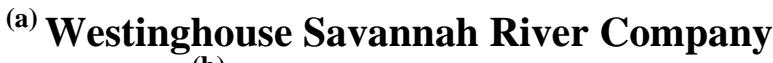

(b) Clemson University

September 30, 2004

Westinghouse Savannah River Company

Savannah River Site

Aiken, SC 29808

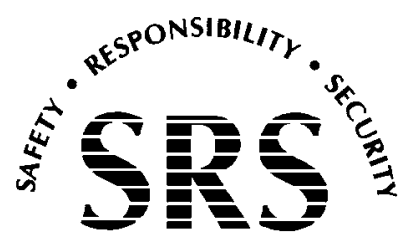

SAVANNAH RIVER SITE

Prepared for the U.S. Department of Energy Under

Contract Number DE-AC09-96SR18500 
This page has been left purposely blank. 
This page was intentionally left blank 
This page was intentionally left blank 


\section{TABLE OF CONTENTS}

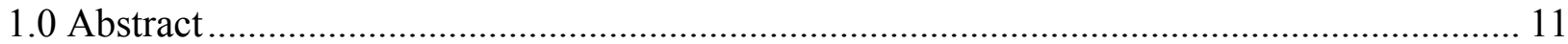

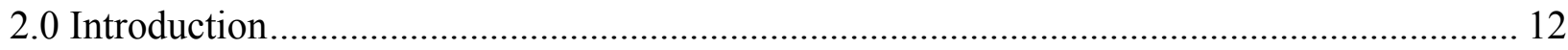

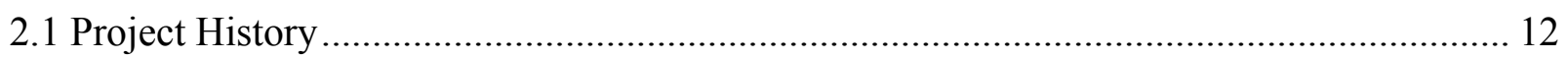

2.2 Synchrotron X-ray Based Studies of Pu Oxidation States in Sediments............................ 14

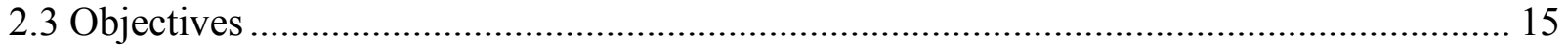

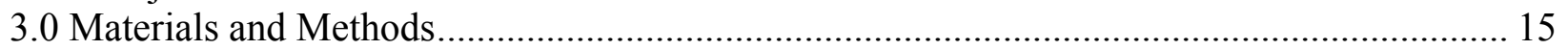

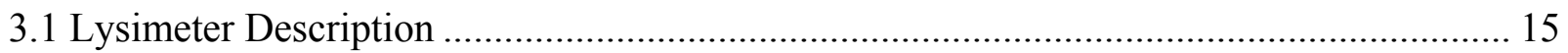

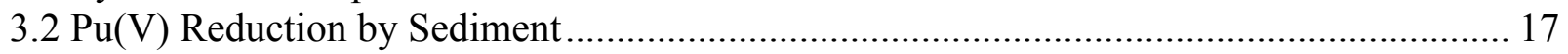

3.3 Sediment Pu Oxidation State Distribution By Wet Chemistry Techniques ........................ 17

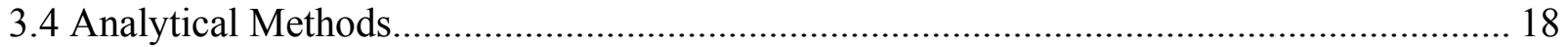

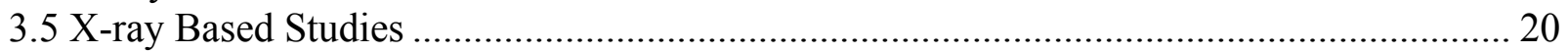

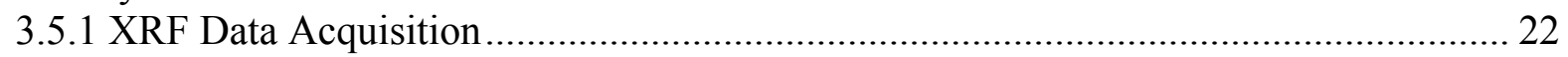

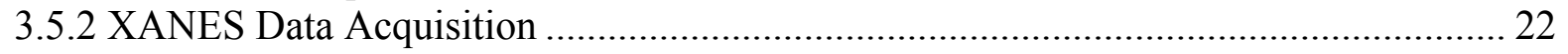

3.6 Reactive Transport Modeling ................................................................................... 22

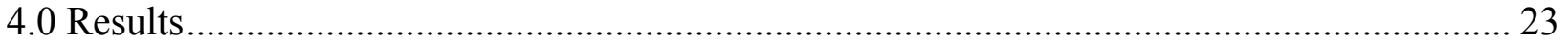

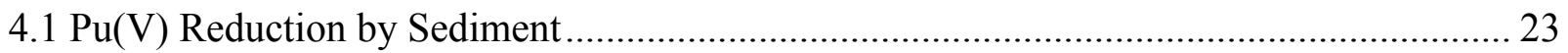

4.2 Sediment Pu Oxidation-State Distribution By Wet chemsitry Techniques.......................... 27

4.3 X-ray Based Characterization of Sediments and Filters..................................................... 28

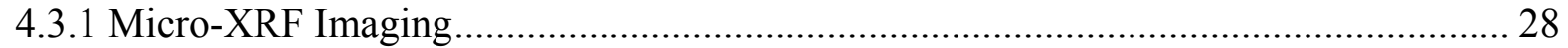

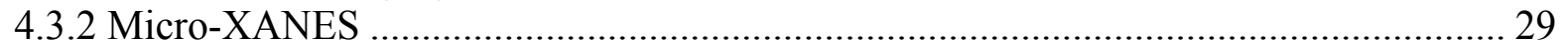

4.4 Plutonium Concentrations As a Function of Depth in the Lysimeters ............................... 36

4.4.1 Comparison of Sediment Pu Concentration Distributions in $\mathrm{Pu}(\mathrm{III})$ and $\mathrm{Pu}(\mathrm{IV})$ Treated

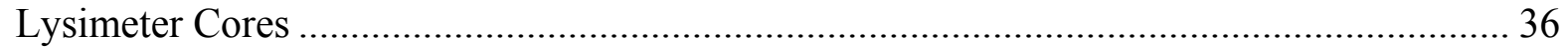

4.4.2 Comparison of Sediment Pu Concentration Distributions in $\mathrm{Pu}(\mathrm{IV})$ and $\mathrm{Pu}(\mathrm{VI})$ Treated

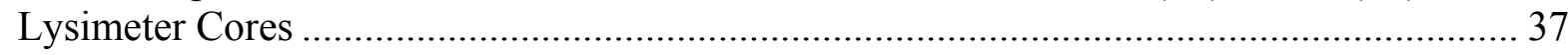

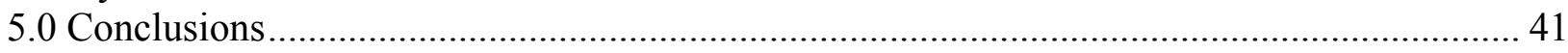

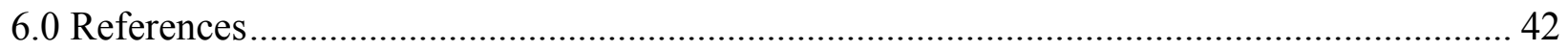

7.0 Appendix A: Detailed Description of Materials and Methods ............................................. 45

7.1 Materials and Methods For Recovering Depth-Discrete Samples from the Mini-lysimeter

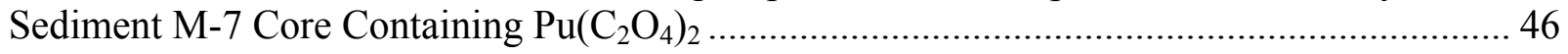

7.2 Materials and Methods For Recovering Depth-Discrete Samples from the Mini-lysimeter

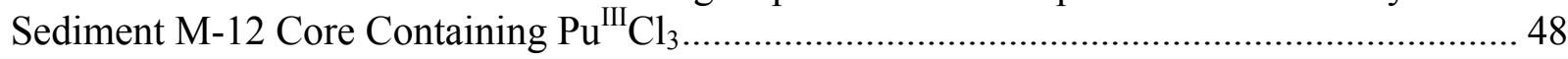

7.3 Materials and Methods for Preparing National Synchrotron Light Source Samples .......... 50

8.0 Appendix B: Additional Micro-XRF Elemental Maps........................................................ 53 


\section{LIST OF FIGURES}

Figure 1. Schematic of the lysimeter used in this study. Source consisted of $\mathrm{Pu}(\mathrm{III}), \mathrm{Pu}(\mathrm{IV})$, or $\mathrm{Pu}(\mathrm{VI})$ added as a liquid to filter paper and then sandwiched between two clean filter papers. Lysimeters were left exposed to natural conditions for 2 or 11 years. 19

Figure 2. Thorium(IV), $\mathrm{Np}(\mathrm{V})$, and $\mathrm{U}(\mathrm{VI})$ aqueous concentrations in contact with the lysimeter sediment after a $1 \mathrm{~h}$ (ad)sorption step (white bars), followed by a 0.25 -hr $\mathrm{pH} 1.5$ desorption step (black bars).

Figure 3. Top: Oxidation state of sediment $\mathrm{Pu}$ following aqueous $\mathrm{Pu}(\mathrm{V})$ addition to lysimeter sediment suspensions (suspended solids $=25,000 \mathrm{mg} \mathrm{L}^{-1}$; background electrolyte $=0.02 \mathrm{M}$ $\mathrm{NaCl}$; mean and standard deviation of 2 replicates). Bottom: Pseudo first-order reduction

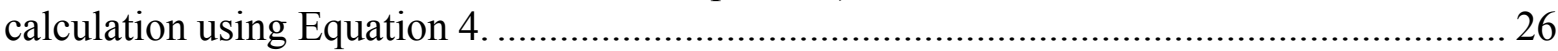

Figure 4. Plutonium oxidation-state distribution in three lysimeter sediments (average and standard deviation at one sigma of three replicate measurements)..................................... 28

Figure 5. Microprobe-XRF spectrum taken at region "A" on sediment from Lysimeter \#9$\mathrm{Pu}\left(\mathrm{NO}_{3}\right)_{4}$. This sediment sample was taken from where the $\mathrm{Pu}(\mathrm{IV})$-spiked filter made contact with the sediment. Elemental regions of interest (shown in blue) were selected for calcium, iron, manganese, zinc, lead, uranium, $\mathrm{Pu}$, and zirconium.

Figure 8. Correlation plot of microprobe-SXRF image of plutonium (red) and iron (blue) in sediment next to the $\mathrm{Pu}(\mathrm{IV})$-spiked filter in $\mathrm{Pu}\left(\mathrm{NO}_{3}\right)_{4}$ lysimeter; the highest plutonium-iron correlations are represented in pink. Figures 6 and 7 include maps of other elements from the same sample location. .............................................................................................. 33

Figure 9. The Pu-XANES spectra for the standards [Pu(IV) and (VI)] and regions " $\mathrm{C}$ " and "A" on the sediment taken next to the $\mathrm{Pu}(\mathrm{IV})$-spiked filter in Lysimeter $\# 9-\mathrm{Pu}\left(\mathrm{NO}_{3}\right)_{4}$. The spectra demonstrate the edge energy shift with oxidation state at the half height of the edge step (i.e., when Normalized Fluorescence Counts $=0.5$ ). The average edge energy for sediment from Lysimeter \#9-Pu(NO 3$)_{4}$ (region C) is roughly midway between $\mathrm{Pu}(\mathrm{III})$ and $\mathrm{Pu}(\mathrm{IV})$ which, based on relative edge energy, would be consistent with a mixed $\mathrm{Pu}(\mathrm{III} / \mathrm{IV})$ species.

Figure 10. Total sediment $\mathrm{Pu}$ concentrations in $\mathrm{Pu}(\mathrm{III})$ and $\mathrm{Pu}(\mathrm{IV})$ lysimeters after 11 years.... 37

Figure 11. Total Pu concentration of four lysimeters after two or eleven years.......................... 38

Figure 12. Normalized total $\mathrm{Pu}$ sediment concentrations $\left(\mathrm{Pu} / \mathrm{Pu}_{0}\right)$ in the $\mathrm{Pu}^{\mathrm{IV}}\left(\mathrm{NO}_{3}\right)_{4}$ amended lysimeter. Diamond symbols represent measured values. Simulation input values ( $k o$ and $k r$ are the first-order rate constants for $\mathrm{Pu}(\mathrm{IV})$ oxidation and $\mathrm{Pu}(\mathrm{V} / \mathrm{VI})$ reduction, respectively): (1) $k o=0 \mathrm{~h}^{-1}, k r=0 \mathrm{~h}^{-1}$; (2) $k o=1 \mathrm{e}-5 \mathrm{~h}^{-1}, k r=0 \mathrm{~h}^{-1}$; (3) $k o=1 \mathrm{e}-8 \mathrm{~h}^{-1}, k r=1.2 \mathrm{e}-3 \mathrm{~h}^{-1}$. A reduction and oxidation term was included in simulation (3).

Figure 13. Normalized total $\mathrm{Pu}$ sediment concentrations $\left(\mathrm{Pu} / \mathrm{Pu}_{0}\right)$ in the $\mathrm{Pu}^{\mathrm{II}} \mathrm{O}_{2}\left(\mathrm{NO}_{3}\right)_{2}$-amended lysimeter. Diamond symbols represent measured values. Simulation input values ( $k o$ and $k r$ are the first-order rate constants for $\mathrm{Pu}(\mathrm{IV})$ oxidation and $\mathrm{Pu}(\mathrm{V} / \mathrm{VI})$ reduction, respectively): (1) $k o=0 \mathrm{hr}^{-1}, k r=0 \mathrm{hr}^{-1}$; (2) $k o=0 \mathrm{hr}^{-1}, k r=1 \mathrm{e}-5 \mathrm{hr}^{-1}$; (3) $k o=0 \mathrm{hr}^{-1}, k r=2.0 \mathrm{e}-4 \mathrm{hr}^{-1}$; and (4) $k o=1.0 \mathrm{e}-6 \mathrm{hr}^{-1}, k r=2.0 \mathrm{e}-4 \mathrm{hr}^{-1}$. There was near identical simulations with or without an oxidation term, simulation 4 and 3 , respectively. 40 


\section{LIST OF TABLES}

Table 1. Selected Physical and Chemical Properties of the Lysimeter Sediment. ....................... 16

Table 2. Sample Description for XAS Analysis.......................................................................... 21

Table 3. The calculated average distribution for $\mathrm{Pu}(\mathrm{III})$ and $\mathrm{Pu}(\mathrm{IV})$ in the lysimeter samples based on edge energy in comparison to spectra for $\mathrm{Pu}(\mathrm{IV})$ in $\mathrm{PuO}_{2}$ (s) and $\mathrm{Pu}(\mathrm{III})$ in $\mathrm{PuBr}_{3}(\mathrm{~s}){ }^{(\mathrm{a})}$

\section{ACRONYMS}

$\begin{aligned} \text { CA } & \text { Composite Analysis } \\ \text { EXAFS } & \text { Extended-X-Ray Absorption Fine Structure } \\ \text { OM } & \text { Organic matter } \\ \text { PA } & \text { Performance Assessment } \\ \text { XANES } & \text { X-Ray Absorption Near-Edge Structure } \\ \text { XRF } & \text { X-Ray Fluorescence } \\ \text { SA } & \text { Special Analysis } \\ \text { SRS } & \text { Savannah River Site } \\ \text { WSRC } & \text { Westinghouse Savannah River Company }\end{aligned}$


This page has been left purposely blank. 


\subsection{ABSTRACT}

The Savannah River Site (SRS) contains a large inventory of plutonium $(\mathrm{Pu})$, some of it in the form of Low-Level Waste (LLW). Much of this LLW has been or will be disposed at the EArea LLW Facility. As part of the permitting of LLW on-site disposal, SRS is required to periodically update the Performance Assessment calculations used in part to establish the facility specific amount of waste that can be safely disposed (or establish the Waste Acceptance Criteria). The objective of this project was to determine if a recent discovered change in plutonium chemistry (i.e., oxidation of $\mathrm{PuO}_{2}$, a common form of $\mathrm{Pu}$ waste, may form plutonium in the more mobile hexavalent form, Haschke et al. (2000)) was within the assumptions, parameters, and bases of the approved Performance Assessment WSRC (2000) and Composite Assessment, WSRC (1997). This project was initiated in 2001, and this is the final report describing laboratory and lysimeter (field) studies.

Results from this year's work provided additional technical support for the conceptual $\mathrm{Pu}$ geochemical model proposed for future risk-based calculations (Kaplan 2004). When lysimeters containing $\mathrm{Pu}(\mathrm{III})$ or $\mathrm{Pu}(\mathrm{IV})$ were left exposed to the natural environment for 11 years, essentially all of the sediment-bound $\mathrm{Pu}$ existed as $\mathrm{Pu}(\mathrm{IV})$ and possibly $\mathrm{Pu}(\mathrm{III})$, the least mobile forms of $\mathrm{Pu}$. This result was confirmed by two independent measurements, a very sensitive, indirect wet-chemistry method and a less-sensitive, direct spectroscopic technique, micro-X-ray adsorption near-edge structure (micro-XANES) spectroscopy. In these lysimeters, Pu sediment concentrations decreased on average an order-of-magnitude per centimeter for the first $5 \mathrm{~cm}$ below the source, an astounding rate of contaminant retardation. When $\mathrm{Pu}(\mathrm{VI})$, the more mobile form, which Haschke et al (2000) proposed may form from $\mathrm{PuO}_{2}$, was added to the lysimeters, the Pu moved faster than it had in the other lysimeters: Pu moving on average $12.5 \mathrm{~cm} / \mathrm{yr}$ in the $\mathrm{Pu}(\mathrm{VI})$ lysimeter, compared to $0.9 \mathrm{~cm} / \mathrm{yr}$ in the $\mathrm{Pu}(\mathrm{III})$ and $\mathrm{Pu}(\mathrm{IV})$ lysimeters. Importantly, transport modeling of the data clearly suggested that reduction of the original $\mathrm{Pu}(\mathrm{VI})$ occurred, thus most of the transport of the $\mathrm{Pu}$ in the lysimeter must have progressed during the early portion of the study, prior to the sediment-induced reduction of $\mathrm{Pu}(\mathrm{VI})$. When $\mathrm{Pu}(\mathrm{V})$ was added to the lysimeter sediment in a laboratory study, the $\mathrm{Pu}(\mathrm{V})$ quickly reduced to $\mathrm{Pu}(\mathrm{IV})$ within a couple days. These data together with those from previous reports for this project conclusively show that $\mathrm{Pu}$, irrespective of the form it is introduced into SRS sediments, tends to convert rapidly to the +4 , and possible +3 , oxidation state, the least mobile form of $\mathrm{Pu}$. 
WSRC-TR-2004-00493, REV. 0

\subsection{INTRODUCTION}

\subsection{PROJECT HISTORY}

One intent of DOE Order 435.1, U.S. DOE (1999a), as expressed in the performance assessment/composite analysis guidance, U.S. DOE (1999b), is to ensure that proposed or discovered changes in waste forms, containers, radionuclide inventories, facility design, and operations are reviewed to ensure that the assumptions, results, and conclusions of the DOE approved performance assessment (WSRC 2000), composite analysis (WSRC 1997), as well as any special analyses that might have been performed, remain valid (i.e., that the change or discovery is bounded by the performance assessment and composite analysis) and the change or discovery is within the bounds of the Disposal Authorization Statement, U.S. DOE. (1999c). The goal of this Order is to provide flexibility in day-to-day operation and to require those issues with a significant impact on the performance assessment's conclusions to be identified and given the proper level of attention. It should be noted that the term performance measure is used to describe site-specific adaptations of the DOE Order 435.1 Performance Objectives and requirements (e.g., performance measures such as applying drinking water standards to the groundwater impacts assessment).

The overall objective of this project was to determine if a recently discovered change in our understanding of plutonium chemistry (discussed below; Haschke et al. 2000) is within the assumptions, parameters, and bases of the approved performance assessment (WSRC 2000) and composite assessment (WSRC 1997). If this change in understanding of Pu chemistry is consistent with the calculations in the performance assessment, then the documents generated from this project would serve as the technical basis for continued disposal of LLW containing $\mathrm{Pu}$. If not, then in order to continue Pu-bearing LLW disposal, the performance assessment and composite assessment would need to be updated as appropriate and DOE approval sought for the update (special analysis or revision of the performance assessment and composite analysis). Alternatively, compensatory measures (e.g., restricting disposal of Pu-bearing waste) could be taken.

The work of Haschke et al. (2000) showed that $\mathrm{PuO}_{2}$ is not the thermodynamically stable form as was previously thought. In humid environments or the presence of water, some of the $\mathrm{Pu}$ is oxidized to $\mathrm{Pu}(\mathrm{VI})$ with the evolution of hydrogen and the formation of $\mathrm{PuO}_{2+\mathrm{x}}$, where $\mathrm{x}$ can range up to 0.27 (i.e. about $27 \%$ of the $\mathrm{Pu}$ has been oxidized from the +4 to the +6 oxidation state). The implication of this discovery is that a more mobile form of $\mathrm{Pu}, \mathrm{Pu}(\mathrm{VI})$, than that assumed in the performance assessment, $\mathrm{Pu}(\mathrm{IV})$, could be present in the humid waste disposal environment. If so, then the approved performance assessment might not conservatively bound the effects of $\mathrm{Pu}$ waste disposal.

To address this issue, Kaplan and Wilhite (2001) conducted a literature review. They concluded that Haschke's discovery would not impact LLW disposal at SRS because any Pu(VI) that might form would likely be rapidly reduced to $\mathrm{Pu}(\mathrm{IV})$ before it could migrate far from the disposed waste and because the $\mathrm{Pu} \mathrm{K}_{\mathrm{d}}$ used in the performance assessment was likely a 
conservative representation of the Pu oxidation state mixture that could exist in SRS waste. Nonetheless, additional SRS studies were recommended as a component of performance assessment maintenance to demonstrate the fate of $\mathrm{Pu}(\mathrm{VI})$ in the SRS environment.

As a result of this latter recommendation, laboratory and field experiments were conducted to provide the technical guidance for a $\mathrm{Pu}$ geochemical conceptual model that can be used in future performance assessments and composite analyses. The single most important finding from these studies was regardless of the $\mathrm{Pu}$ oxidation state added to SRS sediments, $\mathrm{Pu}$ was quickly converted to the less mobile Pu(IV) form (Kaplan et al. 2003, Kaplan et al. 2004). This was demonstrated in several different experiments (steady state and kinetic experiments) and with several SRS sediments under a wide range of experimental conditions. When $\mathrm{Pu}(\mathrm{V}), \mathrm{a}$ mobile form of $\mathrm{Pu}$, was added to a SRS sediment, direct measurements of the oxidation state showed that essentially all of the $\mathrm{Pu}$ had been reduced to $\mathrm{Pu}(\mathrm{IV})$ within one day. Similarly, when $\mathrm{Pu}(\mathrm{V})$ was added to four widely different SRS sediments, the tendency for the Pu to sorb to the sediment changed over time; initially the Pu sorbed weakly to the sediment and after 33 days the $\mathrm{Pu}$ sorbed to the sediment in a manner similar to that of $\mathrm{Pu}(\mathrm{IV})$. Finally, $\mathrm{Pu}(\mathrm{VI})$ was found to be extremely unstable under conditions expected to exist in the SRS subsurface; reducing on the timeframe of minutes from $\mathrm{Pu}(\mathrm{VI})$ to $\mathrm{Pu}(\mathrm{V})$.

A 52-L lysimeter containing sediment from the SRS and solid $\mathrm{Pu}(\mathrm{IV})$ was left exposed to natural wetting and drying cycles for 11 years before the lysimeter sediment was sampled for $\mathrm{Pu}$ concentration distribution (Kaplan et al. 2001). The added $\mathrm{Pu}$ had traveled $10 \mathrm{~cm}$, with $>95 \%$ of the $\mathrm{Pu}$ remaining within $1.25 \mathrm{~cm}$ of the source. Laboratory experiments showed that the lysimeter sediment could readily reduce $\mathrm{Pu}(\mathrm{V})$ to $\mathrm{Pu}(\mathrm{IV})$. Of particular interest was that this same sediment could potentially be induced to release very low concentrations of sorbed $\mathrm{Pu}$ under oxidizing conditions, presumably by oxidation of sorbed $\mathrm{Pu}(\mathrm{IV})$ to the more mobile $\mathrm{Pu}(\mathrm{V})$ species. Transport modeling supported the postulate that $\mathrm{Pu}$ oxidation occurred in the lysimeter sediment; the inclusion of an oxidation term in the model produced simulations that captured the $\mathrm{Pu}$ depth profile data. The laboratory and long-term lysimeter studies revealed that both oxidation and reduction mechanisms can play an important role in $\mathrm{Pu}$ transport through the vadose zone and should be considered when evaluating disposal of Pu-bearing wastes on the SRS (Fjeld et al. 2004; Kaplan et al. 2003; Kaplan et al. 2004).

Most recently, a conceptual model describing Pu geochemistry in the SRS, along with input values, was developed based on the lysimeter and laboratory work conducted for this project (Kaplan 2004). The conceptual model assumed that $\mathrm{Pu}$ existed in two oxidation states, $\mathrm{Pu}(\mathrm{III} / \mathrm{IV})$ and $\mathrm{Pu}(\mathrm{V} / \mathrm{VI})$. The experimental results showed that $>95 \%$ of all $\mathrm{Pu}$ existed as $\mathrm{Pu}(\mathrm{IV})$ and 1 to $5 \%$ existed as $\mathrm{Pu}(\mathrm{V})$. It was also assumed that all the $\mathrm{Pu}$ in the source term initially existed as $\mathrm{Pu}(\mathrm{III} / \mathrm{IV})$. Groundwater $\mathrm{Pu}$ concentrations in and near the source term were controlled by solubility constraints, as described by a solubility constant for $\mathrm{PuO}_{2(s)}$. $\mathrm{Pu}$ concentrations after it left the source term and entered the engineered barrier or sediment was controlled by kinetic oxidation-reduction rate terms (describing the conversions between $\mathrm{Pu}(\mathrm{III} / \mathrm{IV})$ and $\mathrm{Pu}(\mathrm{V} / \mathrm{VI})$ ) and steady state sorption (as described by $\mathrm{K}_{\mathrm{d}}$ values). $\mathrm{Pu}(\mathrm{III} / \mathrm{IV}$ ) and $\mathrm{Pu}(\mathrm{V} / \mathrm{VI})$ in the system were assigned unique $\mathrm{K}_{\mathrm{d}}$ values and unique first-order oxidation and first-order reduction rate from laboratory experiments (Kaplan et al. 2004). Also included in the conceptual model was colloid-facilitated transport of $\mathrm{Pu}$, for which input values were based on $\mathrm{Pu}$-colloid 
concentration field data collected from F-Area groundwater samples (Kaplan et al. 1994). This conceptual model and the input values have since been incorporated into two recent Special Analysis calculations for the slit and engineered trench (Collard and Hiergesell 2004) and at the Intermediate Level Vaults (Flach and Hiergesell 2004). The technically supported conceptual model and input values for the model provided justification for reducing costly conservatism necessary in earlier calculations (McDowell-Boyer 2000).

\subsection{SYNCHROTRON X-RAY BASED STUDIES OF Pu OXIDATION STATES IN SEDIMENTS}

Part of this project investigated $\mathrm{Pu}$ (added as dissolved $\mathrm{Pu}(\mathrm{III}$ and IV) spiked on filter paper) in soil using in situ spatially resolved synchrotron micro-X-ray fluorescence (microSXRF) imaging and micro-X-ray absorption near-edge structure (micro-XANES) spectroscopy. These X-ray based analytical methods complement other ex situ surface characterization methods for spatially-distributed Pu such as scanning electron microscopy (SEM). With these $\mathrm{X}$-ray based methods, we obtained information on the average oxidation state of sorbed $\mathrm{Pu}$ in soil and on Pu-containing filter paper on a small, two-dimensional spatial scale (about $100 \mu \mathrm{m}$ ).

Micro-SXRF spectroscopy can be used to produce images of elemental distributions on a microscopic level and, therefore, is a valuable technique for determining the micro-distributions of sorbed $\mathrm{Pu}$ among various mineral phases in soil and other geologic material. Once identified by SXRF imaging, isolated regions of Pu enrichment may be probed with micro-XANES and extended-X-ray absorption fine structure (EXAFS) techniques. Hence, measurements of bonding environment of particular species on individual mineral micro-phases can be made on these materials. In situ micro-XANES and -EXAFS techniques have been previously utilized to study the local molecular bonding environments of metal contaminants in heterogeneous environmental systems on the micrometer scale (Bertsch et al. 1994).

Few XANES and EXAFS studies have been performed to characterize the local structural speciation of sorbed Pu on natural and synthetic mineral solids (Duff et al. 1998; Duff et al. 1999). These studies were performed with natural geologic samples that contained a variety of minerals (such as zeolites, trace levels of Fe and Mn oxides, and aluminosilicates) with $\mathrm{pH} 9$, carbonate-dominated groundwater simulant solutions. The form of $\mathrm{Pu}$ added was $\mathrm{Pu}(\mathrm{V})$ and the minerals found to sorb the $\mathrm{Pu}$ were mineral assemblages of Mn oxides and the aluminosilicate mineral, smectite. The Pu-XANES studies show that the $\mathrm{Pu}(\mathrm{V})$ was oxidized to $\mathrm{Pu}(\mathrm{VI})$ upon sorption to some of the $\mathrm{Mn}$ oxide-smectite bodies whereas the sorbed $\mathrm{Pu}$ on other $\mathrm{Mn}$ oxidesmectite bodies did not undergo a change in average oxidation state.

Spatially-resolved $\mathrm{Pu}$-XANES studies conducted at the Pu-rich Mn oxide-smectite mineral assemblages, previously spiked with $\mathrm{Pu}(\mathrm{V})$, indicated the average oxidation states of the $\mathrm{Pu}$ was $+\mathrm{V}$ and $+\mathrm{VI}$ (the results were spatially variable). After 2 years, XANES and EXAFS studies show the sorbed $\mathrm{Pu}$ on the Mn oxide-smectite mineral bodies had been reduced to $\mathrm{Pu}(\mathrm{IV}$ ) - suggesting that $\mathrm{Pu}(\mathrm{IV})$ may be the most stable oxidation state of sorbed $\mathrm{Pu}$ over the long term (Duff et al. 2001). The change in speciation may be due to the disproportionation of $\mathrm{Pu}$. 


\subsection{OBJECTIVES}

The objectives of this study were:

1. to measure the change of oxidation state of $\mathrm{Pu}(\mathrm{V})$ added to the Control (unamended) lysimeter sediment,

2. to measure $\mathrm{Pu}$ oxidation state distributions in lysimeter sediments by wet chemistry and synchrotron X-ray based techniques

3. to determine $\mathrm{Pu}$ mobility in two additional 11-year-old lysimeters, containing $\mathrm{Pu}^{\mathrm{IV}}$-oxalate and $\mathrm{Pu}^{\mathrm{III}} \mathrm{Cl}_{3}$, and

4. to compare these results with those previously reported.

The intent of this work was to provide additional technical support for the conceptual model and input values proposed in Kaplan (2004).

\subsection{MATERIALS AND METHODS}

\subsection{LYSIMETER DESCRIPTION}

Four lysimeter cores will be compared in this report:

- Lysimeter \#7: $\mathrm{Pu}^{\mathrm{IV}}\left(\mathrm{C}_{2} \mathrm{O}_{4}\right)_{2}$ (Pu-oxalate)

- Lysimeter \#8: $\mathrm{Pu}^{\mathrm{VI}} \mathrm{O}_{2}\left(\mathrm{NO}_{3}\right)_{2}$

- Lysimeter \#9: $\mathrm{Pu}^{\mathrm{IV}}\left(\mathrm{NO}_{3}\right)_{4}$

- Lysimeter \#12: $\mathrm{Pu}^{\mathrm{III}} \mathrm{Cl}_{3}$

Results from the lysimeters containing $\mathrm{Pu}^{\mathrm{VI}} \mathrm{O}_{2}\left(\mathrm{NO}_{3}\right)_{2}$ and $\mathrm{Pu}^{\mathrm{IV}}\left(\mathrm{NO}_{3}\right)_{4}$ were previously discussed (Kaplan et al. 2003; Kaplan et al. 2004), but will be included in this report for purposes of comparison with the two most recently analyzed lysimeters containing $\mathrm{Pu}^{\mathrm{IV}}\left(\mathrm{C}_{2} \mathrm{O}_{4}\right)_{2}$ and $\mathrm{Pu}^{\mathrm{III}} \mathrm{Cl}_{3}$. The subsurface sediments in these lysimeters were excavated from a shallow trench (or "borrow pit") in E-Area on the SRS. Selected physical and chemical properties of the sediments are presented in Table 1. The sediment had a $\mathrm{pH}$ of about 6.3 , low organic matter concentrations and had a rather high concentration of fine particles: $71 \%$ sand, $10 \%$ silt and $19 \%$ clay. The sediment was red, indicating the presents of Fe-oxyhydroxides. X-ray Diffraction analysis identified the presence of goethite and hematite.

During operations, the lysimeters consisted of inverted 52-L bottomless carboys that were connected to separate leachate collection reservoirs (Figure 1). Between $0.5-0.7 \mathrm{mCi}^{239} \mathrm{Pu}$ from aqueous weapons-grade $\mathrm{Pu}$ were added in the appropriate oxidation state to a filter paper that was buried $21.6 \mathrm{~cm}$ below the lysimeter sediment surface. The lysimeters were left exposed to natural weather conditions for 11 years for all the lysimeters except the lysimeter that received 
$\mathrm{Pu}(\mathrm{VI})$, it remained in the field for only 2 years. ${ }^{1}$ At the end of the 2 or 11 year duration, cores were collected from the lysimeters and subsequently, total Pu concentrations were measured by alpha spectrometry in 1.25 - or $2.5-\mathrm{cm}$, depth-discrete sediment samples. During operation, leachate from the lysimeter was periodically sampled and analyzed for total aqueous $\mathrm{Pu}$ concentrations by alpha spectrometry. A detailed description of the source material preparation is presented in Holcomb (1980).

A detailed description of the procedure used to collect the lysimeter sediment samples as a function of depth is included in Appendix A: Detailed Description of Materials and Methods. A brief description of the procedure follows. Archived lysimeter cores were retrieved from the $4^{\circ} \mathrm{C}$ refrigerator and placed in a Radiation Area hood. The 53-cm long cores were cut into three $\sim 18$ $\mathrm{cm}$ lengths using a hack saw. These core sediments were then extruded in $1.25-$ or $2.5-\mathrm{cm}$ lengths from the metal sleeves by placing in an ELE International Sample Ejector (ELE International, Ltd., London, U.K.). While sectioning the core into 1.25- and 2.5-cm length, care was directed to sample the lower concentration Pu samples before the higher concentration samples to minimize sample cross-contamination. The sediment samples were air dried, homogenized, and then sent to the Analytical Development Section at SRS for microwave digestion followed by total $\mathrm{Pu}$ concentration determination by alpha spectroscopy (described in more detail in Section 3.4).

Table 1. Selected Physical and Chemical Properties of the Lysimeter Sediment.

\begin{tabular}{ll}
\hline Parameter & Value \\
\hline $\mathrm{pH}$ & 6.3 \\
$\mathrm{OM}, \%$ & $<0.01$ \\
sand / silt / clay, \% & $71 \% / 10 \% / 19 \%$ \\
surface area, m $\mathrm{g}^{-1}$ & 13.1 \\
Zero-point-charge $(\mathrm{pH})$ & $5.1 \pm 0.1$ \\
clay mineralogy & Kaolinite $>$ Goethite $>$ Hematite $>$ Gibbsite $>\mathrm{HIV}^{a}$ \\
total Fe, mg kg & 15,888 \\
dithionite extractable Fe, $\mathrm{mg} \mathrm{kg}^{-1}$ & 5346 \\
oxalate extractable Fe, mg kg-1 & 2925 \\
total Mn, mg kg-1 & 630 \\
dithionite extractable Mn, mg kg-1 & 9 \\
oxalate extractable Mn, $\mathrm{mg} \mathrm{kg}^{-1}$ & 4 \\
\hline
\end{tabular}

${ }^{a}$ Relative concentrations of minerals in clay-size $(<2 \mu \mathrm{m})$ fraction based on XRD analysis (HIV $=$ hydroxyl-interlayered vermiculite) .

\footnotetext{
${ }^{1}$ The project that installed the lysimeters in 1980 had originally planned to sample the sediments of all lysimeters, but due to changes in schedule and budget, only one lysimeter was sampled after 2 years.
} 


\subsection{Pu(V) REDUCTION BY SEDIMENT}

The objective of this study was to monitor the oxidation state of sorbed $\mathrm{Pu}$ after adding a ${ }^{239} \mathrm{Pu}(\mathrm{V})$ spike solution to the control (unamended) lysimeter sediment. A $0.3-\mathrm{mL}$ aliquot of a $5.0 \times 10^{-7} M^{239} \mathrm{Pu}(\mathrm{V})$ spike solution was added to centrifuge tubes containing $24.3 \pm 0.4 \mathrm{~g} \mathrm{~L}^{-1}$ sediment suspension in $0.02 \mathrm{M} \mathrm{NaCl}$. The spike solution contained $98 \pm 3 \% \mathrm{Pu}(\mathrm{V})$ at time zero and the aqueous phase contained $99 \pm 6 \% \mathrm{Pu}(\mathrm{V})$ at the conclusion of the experiment. The samples were mixed in the dark for up to $3000 \mathrm{~min}$. Control samples containing no solid phase were prepared to monitor the stability of $\mathrm{Pu}(\mathrm{V})$ over the course of the experiment (no changes in $\mathrm{Pu}$ oxidation states were observed in these controls).

The $\mathrm{Pu}^{\mathrm{V}} \mathrm{O}_{2}{ }^{+}{ }_{(a q)}$ spike solution was prepared by the method of Satio et al. (1985). Briefly, $6.75 \times 10^{-5} M^{239} \mathrm{Pu}^{1 \mathrm{~V}}\left(\mathrm{NO}_{3}\right)_{4}$ (Isotope Products, Valencia, CA) in $4.0 \mathrm{MHNO}_{3}$ was mixed with 1 x $10^{-3} \mathrm{M} \mathrm{KMnO}_{4}$ in $1.0 \mathrm{M} \mathrm{HNO}_{3}$ for $6 \mathrm{~h}$ in the dark to oxidize $\mathrm{Pu}(\mathrm{IV})$ to $\mathrm{Pu}(\mathrm{VI})$. Then $\mathrm{Pu}(\mathrm{VI})$ was extracted into a solution of $0.5 \mathrm{M}$ TTA in cyclohexane. This organic phase was irradiated using fluorescent room light to reduce $\mathrm{Pu}(\mathrm{VI})$ to $\mathrm{Pu}(\mathrm{V})$. The $\mathrm{Pu}(\mathrm{V})$ was then back-extracted into $0.02 \mathrm{M} \mathrm{NaCl}$ at $\mathrm{pH}$ 4.5. The final $\mathrm{Pu}(\mathrm{V})$ solution was diluted to $1.3 \times 10^{-8} \mathrm{MPu}(\mathrm{V})$ and adjusted to $\mathrm{pH} 5.0$.

\subsection{SEDIMENT Pu OXIDATION STATE DISTRIBUTION BY WET CHEMISTRY TECHNIQUES}

$\mathrm{Pu}$ oxidation state distribution was determined from one sediment sample from each of the following lysimeters: Lysimeter \#7: $\mathrm{Pu}^{\mathrm{IV}}\left(\mathrm{C}_{2} \mathrm{O}_{4}\right)_{2}$ (Pu-oxalate), Lysimeter \#9: $\mathrm{Pu}^{\mathrm{IV}}\left(\mathrm{NO}_{3}\right)_{4}$, and Lysimeter \#12: $\mathrm{Pu}^{\mathrm{III}} \mathrm{Cl}_{3}$. Sediment samples with high $\mathrm{Pu}$ sediment concentrations located immediately below the source were selected for this analysis to ensure more accurate analyticalcounting statistics.

$\mathrm{Pu}$ oxidation state distribution was determined by the method used by Kenney-Kennicutt and Morse (1985) and revised by Morgenstern and Choppin (2002) and Powell et al. (2004). The procedure permits monitoring the oxidation state distribution in both the solid and aqueous phases by measuring the $\mathrm{Pu}$ oxidation state before and after acidifying the sample to desorb $\mathrm{Pu}$ from the solid phase. Briefly, a $2.5 \mathrm{~mL}$ suspension aliquot was passed through a 12 -nm filter (Microsep 30K MWCO Omega Membrane Centrifugal Device; Pall Corporation, East Hills, $\mathrm{NY}$ ) and the filtrate was then analyzed for $\mathrm{Pu}$ oxidation state distribution by the thenolytrifluoroacetone (TTA; Alfa Asear, Ward Hill, MA) and bis-(ethyhexyl)-phosphoric acid (HDEHP; Alfa Asear, Ward Hill, MA) method described below. The remaining $7.5 \mathrm{~mL}$ of the suspension sample was acidified to $\mathrm{pH} 1.5$ using $\mathrm{HClO}_{4}$. It is assumed that this step quantitatively desorbs all the $\mathrm{Pu}(\mathrm{V})$ and $\mathrm{Pu}(\mathrm{VI})$ (and some portion of the $\mathrm{Pu}(\mathrm{IV})$ ); this assumption was tested using $\mathrm{Th}(\mathrm{IV}), \mathrm{Np}(\mathrm{V})$, and $\mathrm{U}(\mathrm{VI})$ analogues (also discussed below). The mass balance equation for the acidified sample is:

$$
[\mathrm{Pu}]_{\text {total }}=[\mathrm{Pu}(\mathrm{IV})]_{\mathrm{solid}}+[\mathrm{Pu}(\mathrm{IV})]_{\mathrm{aq}}+[\mathrm{Pu}(\mathrm{V})]_{\mathrm{aq}}+[\mathrm{Pu}(\mathrm{VI})]_{\mathrm{aq}} .
$$


Importantly, this is an indirect measurement of oxidation state, and as such is limited by its underlying assumptions. Micro-XANES offers a direct measurement of Pu oxidation states (discussed in Section 2.2). Analogue conformational studies were conducted in which ${ }^{230} \mathrm{Th}(\mathrm{IV})$,

${ }^{237} \mathrm{~Np}(\mathrm{~V})$, or ${ }^{233} \mathrm{U}(\mathrm{VI})$ were added to a $2.5 \mathrm{~g} \mathrm{~L}^{-1}$ control sediment suspension in $0.02 \mathrm{M} \mathrm{NaCl}$. The samples were mixed in the dark for a one-hour adsorption step. The samples were then acidified to $\mathrm{pH} 1.5$, leached for various times, and passed through a $\sim 12-\mathrm{nm}$ filter. The acidified and filtered samples were subjected to $\mathrm{Pu}$ oxidation state analyses, as described above. Additional verification of this technique is presented by Powell et al. (2004). Sediment-free controls containing $\mathrm{Pu}(\mathrm{IV}), \mathrm{Pu}(\mathrm{V})$, and $\mathrm{Pu}(\mathrm{VI})$ solutions were also included in the measurements to confirm that oxidation state of the $\mathrm{Pu}$ in the aqueous state were not altered during the analysis.

\subsection{ANALYTICAL METHODS}

Aqueous $\mathrm{Pu}$ oxidation state distribution analysis was performed by parallel extraction of the $\mathrm{Pu}$ solution into 0.5 M TTA in cyclohexane at $\mathrm{pH} 0.5$ and $0.5 \mathrm{M}$ HDEHP in heptane at $\mathrm{pH} 0.5$ (Bertrand et al. 1982, Kobashi et al. 1988, Neu et al. 1994). Total Pu concentrations were measured with an alpha-beta discriminating liquid scintillation counter (Wallac Inc., Model 1415).

To determine the total $\mathrm{Pu}$ concentration in the lysimeter sediment, an aliquot of each sample was aggressively leached with aqua regia $\left(1\right.$ part $\mathrm{HNO}_{3}$ to 3 parts $\left.\mathrm{HCl}\right) .{ }^{246} \mathrm{Pu}$ spikes were added to each acid digest as a chemical yield tracer; ${ }^{246} \mathrm{Pu}$ was not detected in unspiked samples. All of the $\mathrm{Pu}$ in the samples was reduced using ferric nitrate followed by hydroxylamine, as well as ferrous sulfamate. An anion complexing reagent (aluminum nitrate) was added, and the solutions were oxidized with sodium nitrite. The Pu was then extracted from the matrix using a TTA solution. The TTA layer was mounted on a counting dish and analyzed by alpha spectroscopy.

The control sediment (lysimeter sediment that did not receive any $\mathrm{Pu}$ ) was stored moist and in the dark at $4{ }^{\circ} \mathrm{C}$. All characterization and subsequent equilibration tests were conducted with the sediment in the moist state. Moist samples were used in an effort to minimize experimental artifacts introduced by over drying sediments, such as changing the reactivity of Fe-, Al-, and Mn-oxides or oxidizing organic matter. The sediments were characterized for: $\mathrm{pH}$ in a 1:1 water-sediment slurry; particle-size distribution by the sieve and hydrometer method; zero-pointof-charge by the point-of-zero-salt effect batch method; and free Fe by the dithionite-citrate buffer method (Sparks 1996). Organic matter was determined by the weight-loss-on-ignition method conducted at $360^{\circ} \mathrm{C}$ for $2 \mathrm{~h}$ (Schulte et al. 1991). Mineralogy was determined by x-ray diffraction analyses of the $<2-\mu \mathrm{m}$ fraction that was separated by sedimentation. X-ray diffraction was conducted on samples that were subjected to three sequential heat treatments (for mineral identification purposes): 16 -h at $25{ }^{\circ} \mathrm{C}, 16-\mathrm{h}$ at $65{ }^{\circ} \mathrm{C}$, and then $16-\mathrm{h}$ at $300{ }^{\circ} \mathrm{C}$. 


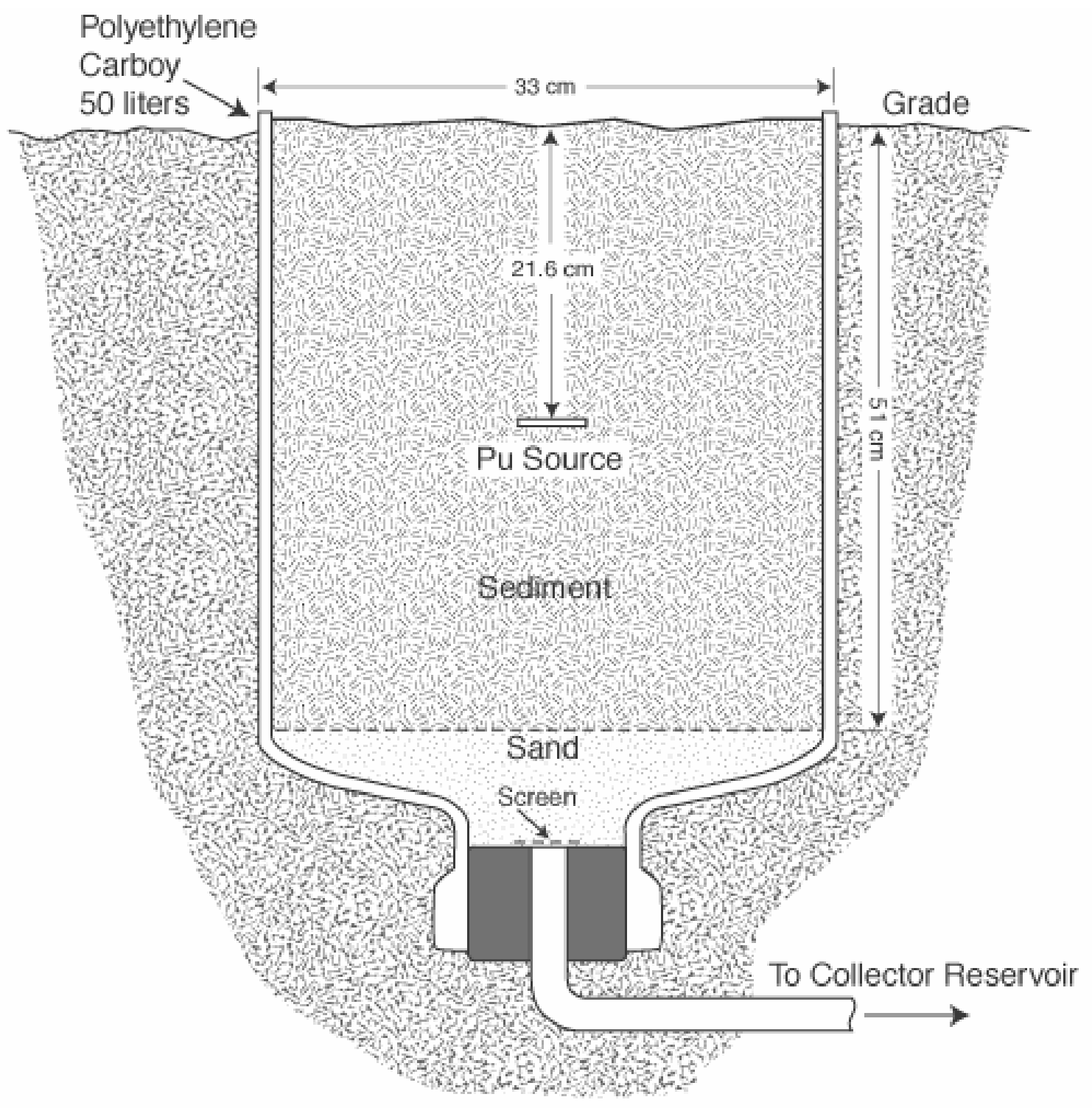

Figure 1. Schematic of the lysimeter used in this study. Source consisted of $\mathrm{Pu}(\mathrm{III}), \mathrm{Pu}(\mathrm{IV})$, or $\mathrm{Pu}(\mathrm{VI})$ added as a liquid to filter paper and then sandwiched between two clean filter papers. Lysimeters were left exposed to natural conditions for 2 or 11 years. 


\subsection{X-RAY BASED STUDIES}

Microprobe XRF and $\mathrm{Pu}-\mathrm{XANES}$ data for $\mathrm{Pu}$ in filters and sediments recovered from the $\mathrm{Pu}(\mathrm{III})$ - and $\mathrm{Pu}(\mathrm{IV})$-amended lysimeters were collected at the National Synchrotron Light Source (NSLS), at the Brookhaven National Laboratory (BNL, Upton, NY) in 2004. For these studies, the synchrotron hard X-ray fluorescence microprobe on the bending magnet at X26A of the NSLS was used with a channel-cut Si(110) monochromator. Microfocusing optics were used to produce the X-ray beam (Eng et al. 1995). A double elliptical Au- or Rh-coated KirkpatrickBaez mirror system angled at 2 mrad was used to focus a 350 - by $350-\mu \mathrm{m}$ monochromatic X-ray beam at the $\mathrm{Pu} \mathrm{L}_{3}$ absorption edge $(18,054 \mathrm{eV})$ to a $10 \mu \mathrm{m}$ vertical by $12 \mu \mathrm{m}$ horizontal beam (Eng et al. 1995).

Sediment and filter paper samples were contained within fitted plastic inserts with polypropylene and kapton windows, placed in a metal frame and mounted on an automated, digital $x-y-z$ stage at $45^{\circ}$ to the beam. Fluorescent X-rays were detected with a Si(Li) energy dispersive (EDS) detector $\left(30 \mathrm{~mm}^{2}\right.$ area) mounted at $90^{\circ}$ to the incident beam and about $1 \mathrm{~cm}$ from the sample. Details of the materials and methods of the sample preparation are included in Appendix A in Section 7.3 Descriptions of the samples prepared for these and future analyses are presented in Table 2. 
Table 2. Sample Description for XAS Analysis.

\begin{tabular}{|c|c|c|c|c|c|c|c|}
\hline ID & Pu added & $\begin{array}{l}\text { Pu-239/40 } \\
\text { (dpm/g) }\end{array}$ & $\begin{array}{l}\text { Pu-238 } \\
(\mathrm{dpm} / \mathrm{g})\end{array}$ & Sample & $\begin{array}{l}\text { Core } \\
\# \\
\end{array}$ & $\begin{array}{l}\text { Pri- } \\
\text { ority }\end{array}$ & Objective \\
\hline$\# 1$ & $\mathrm{Pu}\left(\mathrm{NO}_{3}\right)_{4}$ & $\begin{array}{l}8.01 \mathrm{E} 7 \\
\mathrm{dpm} / \text { filter }\end{array}$ & $\begin{array}{l}\text { 1.67E6 } \\
\text { dpm/filter }\end{array}$ & Filter & M-9 & $\begin{array}{l}1 \\
2\end{array}$ & $\begin{array}{l}\text { (1.) Pu oxidation state } \\
\text { (2.) Elementally define Pu-colloid composition. }\end{array}$ \\
\hline$\# 2$ & $\mathrm{PuCl}_{3}$ & & & Filter & M-12 & $\begin{array}{l}\text { Same } \\
\text { as \#1 }\end{array}$ & Same as \#1 \\
\hline$\# 3$ & $\mathrm{Pu}\left(\mathrm{NO}_{3}\right)_{4}$ & $3.77 \mathrm{E} 6$ & $7.22 \mathrm{E} 4$ & $\begin{array}{l}\text { Sediment from sample } \\
\text { containing filter or } \\
\text { directly in contact with } \\
\text { filter. }\end{array}$ & M-9 & $\begin{array}{l}1 \\
1 \\
3\end{array}$ & $\begin{array}{l}\text { (1.) Elemental (perhaps } \mathrm{Mn}, \mathrm{Fe}, \text { map vs. Pu; are there correlations } \\
\text { between elemental concentrations and } \mathrm{Pu} \\
\text { (2.) Pu oxidation state in sediment. } \\
\text { (3.) Is Pu distributed evenly, in clusters, or as colloids? }\end{array}$ \\
\hline$\# 4$ & $\mathrm{PuCl}_{3}$ & & & $\begin{array}{l}\text { Sediment directly in } \\
\text { contact with filter }\end{array}$ & M-12 & $\begin{array}{l}\text { Same } \\
\text { as \#3 }\end{array}$ & Same as \#3. \\
\hline$\# 5$ & $\mathrm{Pu}\left(\mathrm{NO}_{3}\right)_{4}$ & $3.77 \mathrm{E} 6$ & $7.22 \mathrm{E} 4$ & $\begin{array}{l}<2-\mu \mathrm{m} \text { sediment from } \\
\text { sample containing } \\
\text { filter. }\end{array}$ & M-9 & 1 & $\begin{array}{l}\text { (1) Does } \mathrm{Pu} \text { oxidation state change as a function of distance from } \\
\text { point source. } \\
\text { (2) Is } \mathrm{Pu} \text { in deeper samples colloidal or concentrated in small areas. }\end{array}$ \\
\hline$\# 6$ & $\mathrm{Pu}\left(\mathrm{NO}_{3}\right)_{4}$ & 2070 & 37.8 & $\begin{array}{l}<2-\mu \mathrm{m} \text { sediment from } \\
1-\mathrm{cm} \text { below filter }\end{array}$ & M-9 & $\begin{array}{l}\text { Same } \\
\text { as \#5 }\end{array}$ & Same as \#5 \\
\hline$\# 7$ & $\mathrm{Pu}\left(\mathrm{NO}_{3}\right)_{4}$ & 220 & 4.57 & $\begin{array}{l}<2-\mu \mathrm{m} \text { sediment from } \\
\text { 4-cm below filter }\end{array}$ & M-9 & $\begin{array}{l}\text { Same } \\
\text { as \#5 }\end{array}$ & Same as $\# 5$ \\
\hline$\# 8$ & $\mathrm{Pu}\left(\mathrm{NO}_{3}\right)_{4}$ & 6550 & 15.1 & $\begin{array}{l}<2-\mu \mathrm{m} \text { sediment from } \\
7.28-\mathrm{cm} \text { below filter }\end{array}$ & M-9 & $\begin{array}{l}\text { Same } \\
\text { as \#5 }\end{array}$ & Same as \#5 \\
\hline \multicolumn{8}{|c|}{ Lowest Priority } \\
\hline$\# 9$ & $\mathrm{Pu}\left(\mathrm{C}_{2} \mathrm{H}_{4}\right)_{2}$ & $\begin{array}{l}1.39 \mathrm{E} 8 \\
\mathrm{dpm} / \text { filter }\end{array}$ & $\begin{array}{l}2.55 \mathrm{E} 6 \\
\mathrm{dpm} / \text { filter }\end{array}$ & Filter & M-7 & 3 & Same as \#1 \\
\hline$\# 10$ & $\mathrm{Pu}\left(\mathrm{C}_{2} \mathrm{H}_{4}\right)_{2}$ & $4.62 \mathrm{E} 5$ & 8370 & $\begin{array}{l}\text { Sediment from sample } \\
\text { containing filter or } \\
\text { directly in contact with } \\
\text { filter }\end{array}$ & M-7 & 3 & Same as \#4. \\
\hline
\end{tabular}




\subsubsection{XRF Data Acquisition}

Elemental mappings on the samples were conducted using micro-SXRF imaging at several areas, ranging from 100 by $100 \mu \mathrm{m}^{2}$ to 110 by $110 \mu \mathrm{m}^{2}$ in size. For elements with absorption energies below $18.5 \mathrm{keV}$, SXRF was performed by collecting $20 \mathrm{~s}$ live counts in the elemental regions of interest and rastering the sample in 4 to $5 \mu \mathrm{m}$ steps in the $\mathrm{x}-\mathrm{y}$ plane. Elemental imaging was conducted with the Pu-containing filters and for the sediment samples that were directly associated with the Pu-containing filters. The clay fractions $(<2 \mu \mathrm{m}$ particle size fraction) from the two lysimeter soils (Samples \#9 and \#12; Table 2) were also examined using $\mathrm{XRF}$ analyses.

\subsubsection{XANES Data Acquisition}

The Pu XANES data for oxidation state calibration of Pu was also collected (in 1998) at the NSLS using Pu standards that were provided by Drs. Don T. Reed and Lester Morse (both formerly of Argonne National Laboratory). The standards were embedded in polystyrene resin and placed in Al metal frames. The frames were mounted on an automated, digital $x-y-z$ stage oriented at $45^{\circ}$ to the beam. Fluorescent X-rays were detected with a $\mathrm{Si}(\mathrm{Li})$ energy dispersive detector $\left(30 \mathrm{~mm}^{2}\right.$ area, Canberra) mounted at $90^{\circ}$ to the incident beam and $2 \mathrm{~cm}$ from the standard mounts. Micro-XANES spectra were collected on the Pu L $\alpha$ emission line from $50 \mathrm{eV}$ below the $\mathrm{Pu}$ absorption edge to $180 \mathrm{eV}$ above the Pu edge in varying step increments from 0.4 to $2.5 \mathrm{eV}$. Energy calibration was made with well-characterized Pu solid standards: $\mathrm{PuBr}_{3(\mathrm{~s})}$, $\mathrm{Pu}(\mathrm{IV}) \mathrm{O}_{2(\mathrm{~s})}$ and $\mathrm{Ba}_{3} \mathrm{Pu}(\mathrm{VI}) \mathrm{O}_{6(\mathrm{~s})}$ and a $\mathrm{Zr}$ foil (K-edge at 17,998 eV).

\subsection{REACTIVE TRANSPORT MODELING}

A one-dimensional reactive transport model was used to interpret the sediment $\mathrm{Pu}$ concentration data from the lysimeter study. In this model, described in Fjeld et al. (2004) all the $\mathrm{Pu}$ exists in the +4 and +5 oxidation states, adsorption/desorption occurs in a linear and reversible manner as described by the Kd construct (used in the retardation factors $R_{V}$ and $R_{I V}$ ), and oxidation and reduction of $\mathrm{Pu}$ are described by first-order kinetics. Additionally, water moves by dispersion and advection through the unsaturated sediment at a constant unsaturated water content estimated as $0.3 \mathrm{~cm}^{3} \mathrm{~cm}^{-3}$. The system of equations is:

$$
R_{V} \frac{\partial C_{V}}{\partial t}=-v \frac{\partial C_{V}}{\partial z}+D \frac{\partial^{2} C_{V}}{\partial z^{2}}-k_{r}\left(R_{V}-1\right) C_{V}+k_{o}\left(R_{I V}-1\right) C_{I V}
$$

and 


$$
R_{I V} \frac{\partial C_{I V}}{\partial t}=-v \frac{\partial C_{I V}}{\partial z}+D \frac{\partial^{2} C_{I V}}{\partial z^{2}}+k_{r}\left(R_{V}-1\right) C_{V}-k_{o}\left(R_{I V}-1\right) C_{I V}
$$

where;

$\begin{array}{lll}R_{V}, R_{I V}= & \text { retardation factors for } \mathrm{Pu}(\mathrm{V}) \text { and } \mathrm{Pu}(\mathrm{IV}), \\ C_{V}= & \mathrm{Pu}(\mathrm{V}) \text { aqueous concentration, } \\ C_{I V}= & \mathrm{Pu}(\mathrm{IV}) \text { aqueous concentration, } \\ D & = & \text { dispersion coefficient, } \\ V & = & \text { mean seepage velocity }, \\ k_{r}= & \text { reduction rate constant for } \mathrm{Pu}(\mathrm{V}), \text { and } \\ k_{o} & = & \text { oxidation rate constant for } \mathrm{Pu}(\mathrm{IV}) .\end{array}$

The mean seepage velocity, $v$, was calculated to be $445.8 \mu \mathrm{m} \mathrm{h}^{-1}$, based on the measured average lysimeter discharge rate.

Equations 2 and 3 were solved simultaneously by using a fully implicit finite difference scheme. The $\mathrm{Pu}(\mathrm{V})$ and $\mathrm{Pu}(\mathrm{IV})$ releases from the filter papers were calculated as source terms in the governing equations at the nodes where the filters were located. Upper boundary conditions were set as zero activity concentration and lower boundaries were set to free boundary conditions for both $\mathrm{Pu}(\mathrm{V})$ and $\mathrm{Pu}(\mathrm{IV})$. The activity flux through the bottom boundary was calculated for mass balance purposes.

\subsection{RESULTS}

\subsection{Pu(V) REDUCTION BY SEDIMENT}

To investigate geochemical mechanisms responsible for the Pu depth-profile data observed in the lysimeters, laboratory studies and reactive transport modeling were conducted. For the first laboratory study, the change in Pu oxidation state, both in solution and on the solid phase, was monitored after $\mathrm{Pu}(\mathrm{V})$ was added to a series of tubes containing unamended lysimeter sediment suspensions. In a preliminary test, it was necessary to validate the Pu oxidation state analysis by confirming that all the pentavalent and hexavalent Pu quantitatively desorbed upon lowering the sediment $\mathrm{pH}$ to 1.5 . (It is not necessary for this oxidation state analysis to assume that all $\mathrm{Pu}(\mathrm{IV})$ quantitatively desorbs because all desorbed $\mathrm{Pu}(\mathrm{IV})$ is quantified in the acidified extraction solution, unique from the $\mathrm{Pu}(\mathrm{V})$ and $\mathrm{Pu}(\mathrm{VI})$ concentrations.) ${ }^{230} \mathrm{Th}(\mathrm{IV}),{ }^{237} \mathrm{~Np}(\mathrm{~V})$, and ${ }^{233} \mathrm{U}(\mathrm{VI})$ were added to the sediment as oxidation state analogues in a $1 \mathrm{~h}$ contact and the aqueous concentrations of each analogue was measured (Figure 2). Essentially all the Th(IV) and $\mathrm{U}(\mathrm{VI})$, but very little of the $\mathrm{Np}(\mathrm{V})$ sorbed to the sediment. Upon lowering the sediment $\mathrm{pH}$ to 1.5 , all $(100 \pm 2 \%)$ of the $\mathrm{Np}(\mathrm{V})$ and $\mathrm{U}(\mathrm{VI})$, and very little $(3 \pm 1 \%)$ of the $\mathrm{Th}(\mathrm{IV})$ appeared in the aqueous phase. This is consistent with previous work (Powell et al. 2004) indicating that $\mathrm{Pu}(\mathrm{V})$ and $\mathrm{Pu}(\mathrm{VI})$ can be quantitatively desorbed from pure phase iron oxide minerals using a 15 min leaching step while leaving the $\mathrm{Pu}(\mathrm{IV})$ sorbed to the sediment. 
WSRC-TR-2004-00493, REV. 0

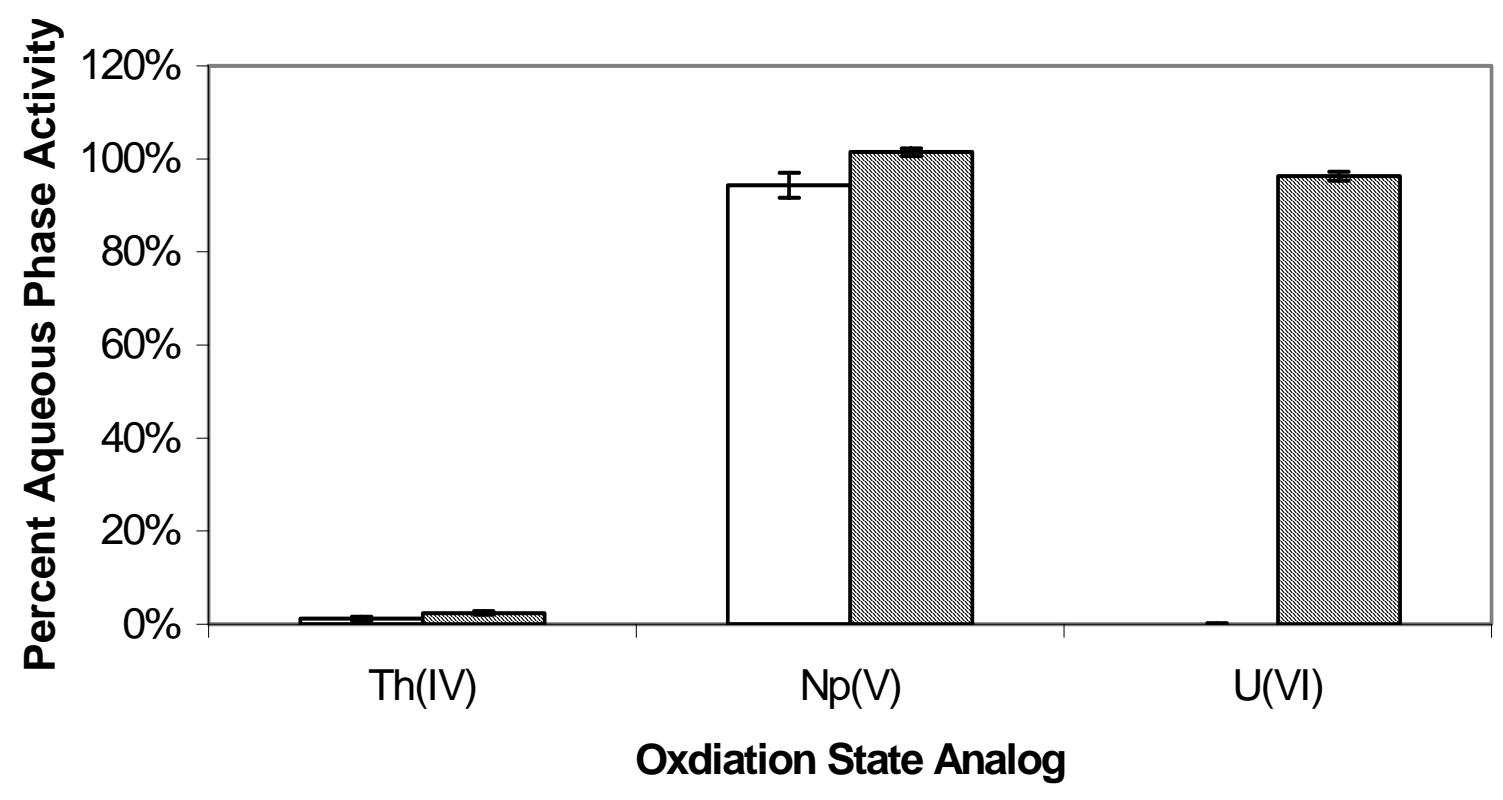

Figure 2. Thorium(IV), $\mathrm{Np}(\mathrm{V})$, and $\mathrm{U}(\mathrm{VI})$ aqueous concentrations in contact with the lysimeter sediment after a $1 \mathrm{~h}(\mathrm{ad})$ sorption step (white bars), followed by a $0.25 \mathrm{-hr} \mathrm{pH} 1.5$ desorption step (black bars).

After adding $\mathrm{Pu}(\mathrm{V})$ to the control lysimeter sediment, the fraction of $\mathrm{Pu}(\mathrm{V})$ on the sediment decreased by half within $370 \mathrm{~min}$ (Figure 3). During this same period, corresponding increases in the percentages of $\mathrm{Pu}(\mathrm{IV})$ were observed. By the end of the 2 day experiment, all of the sorbed $\mathrm{Pu}(\mathrm{V})$ had been converted to $\mathrm{Pu}(\mathrm{IV})$. Noteworthy is that $\mathrm{Pu}(\mathrm{VI})$ concentrations slightly increased during the initial stages of the study. The $\mathrm{Pu}(\mathrm{VI})$ was not introduced as an impurity with the original spike solution. The spike solution at the start and end of the study consisted of $1 \pm 1 \% \mathrm{Pu}(\mathrm{IV}), 98 \pm 3 \% \mathrm{Pu}(\mathrm{V})$, and $1 \pm 1 \% \mathrm{Pu}(\mathrm{VI})$. Powell et al. (2004) observed a similar increase in $\mathrm{Pu}(\mathrm{VI})$ concentrations when $\mathrm{Pu}(\mathrm{V})$ was added to a synthetic magnetite. They attributed the formation of $\mathrm{Pu}(\mathrm{VI})$ to the oxidation of $\mathrm{Pu}(\mathrm{V})$ by $\mathrm{Fe}(\mathrm{III})$ and not to disproportionation. Additionally no disproportionation was observed in control samples without solid phase.

A pseudo-first order rate constant with respect to Pu concentrations, $k^{\prime}{ }_{r e d}$ (Equation 4), was calculated from the disappearance of $\mathrm{Pu}(\mathrm{V})$ using the data in Figure 3:

$$
\ln \left(\frac{[P u(I V)]}{1-[P u(I V)]_{\text {initial }}}\right)=-k_{\text {red }}^{\prime} t
$$

The calculated rate constant was $0.112 \pm 0.007 \mathrm{~h}^{-1}$. By way of comparison, Fjeld et al. (2003) reported a pseudo first-order rate constant for a sandy Savannah River Site sediment at $\mathrm{pH} 5$ of $0.05 \pm 0.002 \mathrm{~h}^{-1}$. The slower rate measured by Fjeld et al. (2003) can be attributed to the less reactive nature of the sandy versus the loamy texture of the sediment used in this study. 
Plutonium(V) reduction is believed to be induced by various $\mathrm{Fe}(\mathrm{II})$ - or $\mathrm{Fe}(\mathrm{III})$-bearing minerals commonly identified in these sediments, such as ilmenite $\left(\mathrm{FeTiO}_{3}\right)$, biotite $\left(\mathrm{K}[\mathrm{Mg}, \mathrm{Fe}]_{3}[\mathrm{Al}, \mathrm{Fe}] \mathrm{Si}_{3} \mathrm{O}_{10}[\mathrm{OH}, \mathrm{F}]_{2}\right)$, magnetite/maghemite $\left(\mathrm{Fe}^{\mathrm{II}} \mathrm{Fe}^{\mathrm{III}}{ }_{2} \mathrm{O}_{4} / \gamma-\mathrm{Fe}_{2} \mathrm{O}_{3}\right)$, goethite $(\alpha-$ $\mathrm{FeOOH})$ and hematite $\left(\alpha-\mathrm{Fe}_{2} \mathrm{O}_{3}\right)$ or by microbial activity (Denham et al. 1999). The soil contained total elemental concentrations of $630 \mathrm{mg} \mathrm{kg}_{\text {soil }}{ }^{-1} \mathrm{Mn}$ and 15,888 $\mathrm{mg} \mathrm{g}_{\text {soil }}{ }^{-1} \mathrm{Fe}$ (Table 1). 

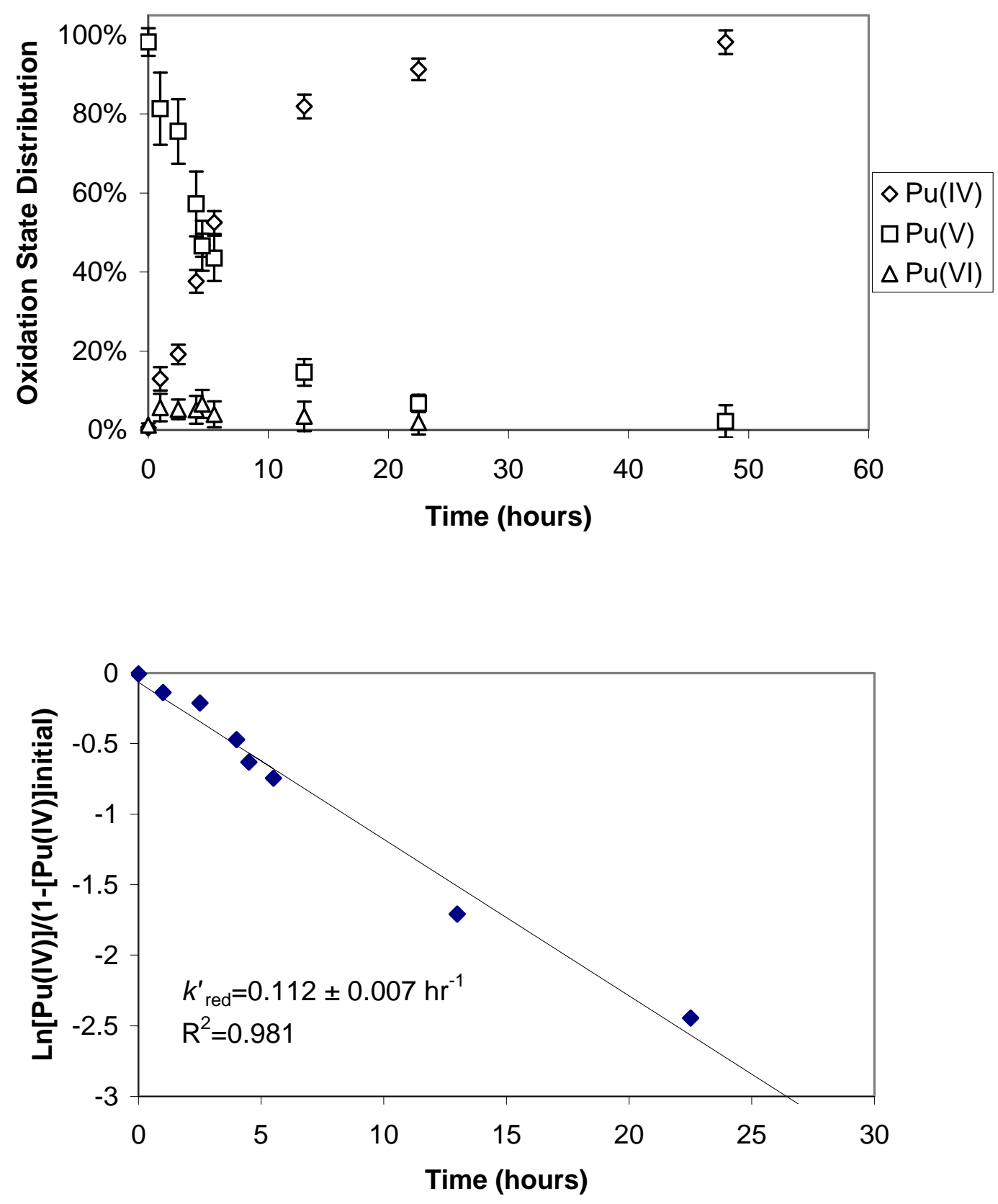

Figure 3. Top: Oxidation state of sediment $\mathrm{Pu}$ following aqueous $\mathrm{Pu}(\mathrm{V})$ addition to lysimeter sediment suspensions (suspended solids $=25,000 \mathrm{mg} \mathrm{L}^{-1}$; background electrolyte $=0.02 \mathrm{M}$ $\mathrm{NaCl}$; mean and standard deviation of 2 replicates). Bottom: Pseudo first-order reduction calculation using Equation 4. 


\subsection{SEDIMENT Pu OXIDATION-STATE DISTRIBUTION BY WET CHEMSITRY TECHNIQUES}

Sediment samples containing the greatest total $\mathrm{Pu}$ concentrations from each of three lysimeters $\left[\mathrm{Pu}^{\mathrm{III}} \mathrm{Cl}_{3}, \mathrm{Pu}^{\mathrm{IV}}\left(\mathrm{NO}_{3}\right)_{4}\right.$, and $\left.\mathrm{Pu}^{\mathrm{IV}}\left(\mathrm{C}_{2} \mathrm{O}_{4}\right)_{2}\right]$ were selected for Pu oxidation-state distribution analyses (Figure 4). The dominant oxidation state of $\mathrm{Pu}$ in all three lysimeters was $\mathrm{Pu}(\mathrm{IV})$, accounting for $>95 \%$ of the total $\mathrm{Pu}$. This confirms the conclusion from the $\mathrm{Pu}(\mathrm{V})-$ reduction experiment described above (Section 4.1) that $\mathrm{Pu}(\mathrm{IV})$ is clearly the predominant oxidation state of $\mathrm{Pu}$ in SRS sediments. The second most abundant oxidation state was $\mathrm{Pu}(\mathrm{III} / \mathrm{V})$, which accounted for essentially the remainder of the sediment $\mathrm{Pu} . \mathrm{Pu}(\mathrm{III})$ and $\mathrm{Pu}(\mathrm{V})$ can not be differentiated by this extraction sequence, and for that reason they are grouped together in one category. Much of the $\mathrm{Pu}(\mathrm{III})$ added to the $\mathrm{Pu}^{\mathrm{III}} \mathrm{Cl}_{3}$ lysimeter sediment had been oxidized to $\mathrm{Pu}(\mathrm{IV})$. This conversion to a more oxidized state was expected based on thermodynamic considerations (Kaplan and Wilhite 2001). The sediment from the $\mathrm{PuCl}_{3}$ lysimeter contained the greatest concentration of $\mathrm{Pu}(\mathrm{III} / \mathrm{V}), 5.2 \pm 1.0 \mathrm{wt}-\%$, presumably some of which remained as $\mathrm{Pu}(\mathrm{III})$. Finally, trace amounts of $\mathrm{Pu}(\mathrm{VI})$ were measured in all three sediments. We included this fraction because it has the potential of being importance to $\mathrm{Pu}$ geochemistry, albeit in trace concentrations, and it is consistent with the findings of the $\mathrm{Pu}$ reduction by sediment experiment, in which trace $\mathrm{Pu}(\mathrm{VI})$ concentrations were also measured (Section 4.1 and Figure 3). 


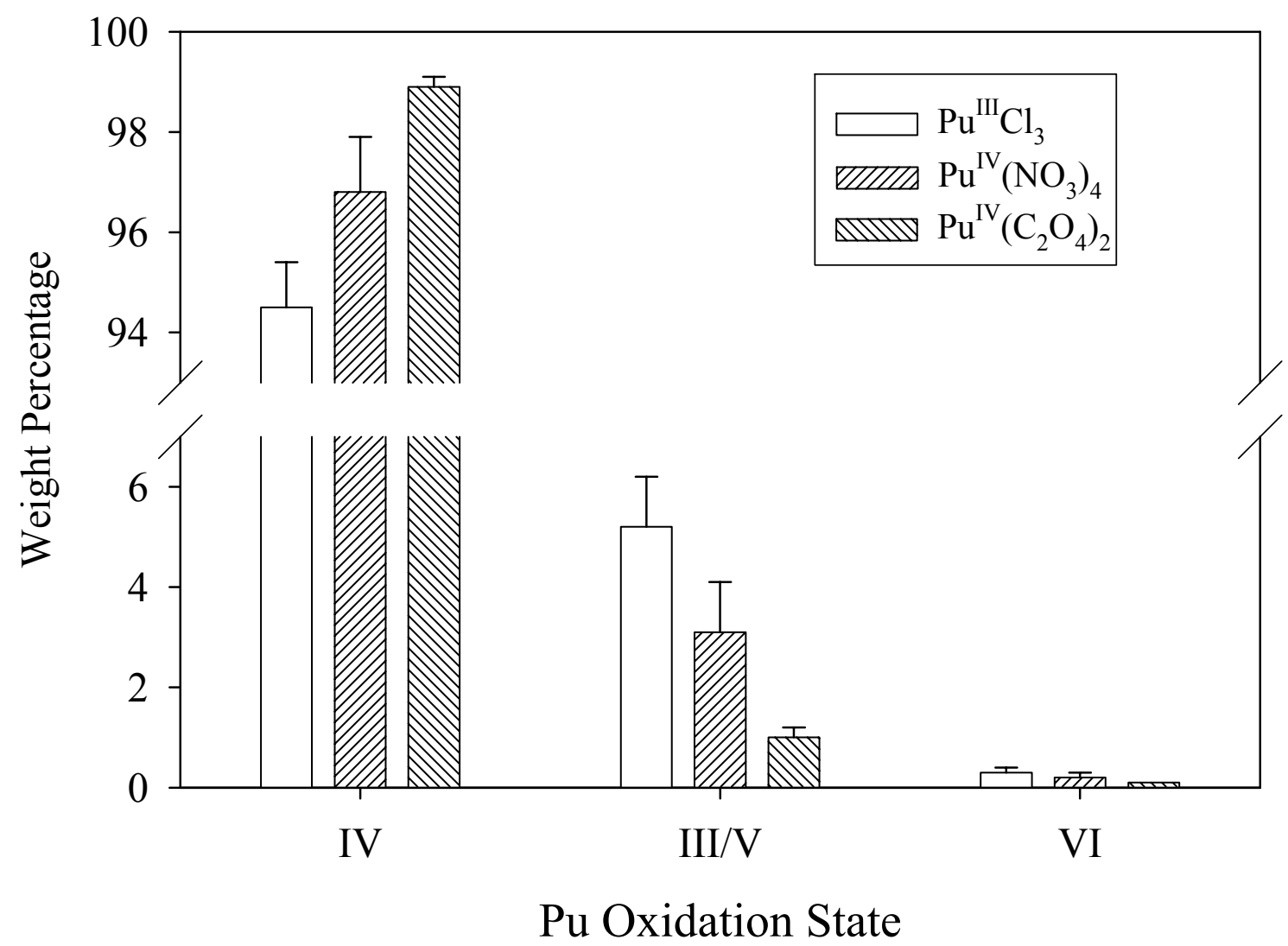

Figure 4. Plutonium oxidation-state distribution in three lysimeter sediments (average and standard deviation at one sigma of three replicate measurements).

\subsection{X-RAY BASED CHARACTERIZATION OF SEDIMENTS AND FILTERS}

\subsubsection{Micro-XRF Imaging}

A representative microprobe-XRF spectrum that was acquired for one of the Pu-containing sediment samples (sediment from Lysimeter $\left.\# 9-\mathrm{Pu}\left(\mathrm{NO}_{3}\right)_{4}\right)$ is shown in Figure 5. For elemental mapping with XRF, regions of interest must be defined in the plot by selecting an energy range (in $\mathrm{keV}$ ) that is specific for the fluorescence emitted by the element of interest. Regions of interest for the elements such as $\mathrm{Ca}, \mathrm{Pb}$, iron ( $\mathrm{Fe}$ ) and $\mathrm{Pu}$ (among others) in sediment from Lysimeter $\# 9-\mathrm{Pu}\left(\mathrm{NO}_{3}\right)_{4}$ are denoted in blue in Figure 5. Elemental images based on microprobe $\mathrm{XRF}$ spectra can be acquired by rastering the sample in $\mathrm{x}$ and $\mathrm{y}$ dimensions and collecting counts in each of the specified energy regions of interest. Several elemental maps for sediment from Lysimeter $\# 9-\mathrm{Pu}\left(\mathrm{NO}_{3}\right)_{4}$ are shown in Figure 6 and Figure 7. 
A correlation XRF plot for Fe versus $\mathrm{Pu}$ is shown in Figure 8 . This plot shows that $\mathrm{Pu}$ in sediment from Lysimeter \#9-Pu( $\left.\mathrm{NO}_{3}\right)_{4}$ is not always associated with iron (with the Fe most likely originating from Fe-oxide minerals in the SRS sediment). This type of relationship (where $\mathrm{Pu}$-concentrated regions in the sediment are not always correlated with the presence of $\mathrm{Fe}$ ) was common for both $\mathrm{Pu}(\mathrm{III})$ - and $\mathrm{Pu}(\mathrm{IV})$-spiked sediments (from Lysimeters \#9-Pu(NO$\left.{ }_{3}\right)_{4}$ and \#12$\mathrm{PuCl}_{3}$; micro-images of these sediments are presented in Section 8.0 Appendix B: Additional Micro-XRF Elemental Maps and in Figure A 1 through Figure A 4). It is possible that this form of $\mathrm{Pu}$, which was not associated with the other elements that were imaged by XRF, is in a colloidal form. However, these XRF data cannot be used to provide information about the $\mathrm{Pu}$ form in these concentrated regions. Further verification of this form would require additional bulk or possibly microprobe extended X-ray absorption fine-structure (EXAFS) spectroscopic analyses, which, given the high Pu levels in the sediment, should be possible.

Despite our previous ability to radiometrically count the Pu levels in the sediments, the $\mathrm{Pu}$ concentrations (on a mass basis) in the clay fractions isolated from the sediments in Lysimeters $\# 9-\mathrm{Pu}\left(\mathrm{NO}_{3}\right)_{4}$ and \#12- $\mathrm{PuCl}_{3}$ were not high enough for quality XRF imaging so elemental maps were not performed. We estimate that these concentrations were in the range of sub $\mu \mathrm{g} \mathrm{Pu}$ per $\mathrm{kg}$ of clay.

\subsubsection{Micro-XANES}

Microprobe Pu-XANES measurements, which provide information on the average oxidation state of $\mathrm{Pu}$ at small spatial regions were conducted with the Lysimeters $\# 9-\mathrm{Pu}\left(\mathrm{NO}_{3}\right)_{4}$ and \#12-PuCl 3 sediment and filter samples. Specifically, these XANES analyses were conducted on the $\mathrm{Pu}$ source terms, i.e., the $\mathrm{Pu}$-spiked filters, the $\mathrm{Pu}$-containing sediments in direct contact with the filters and when possible on the clay fractions associated with the underlying sediment in the lysimeters. Plutonium concentrations on the filters and in the sediments in contact with the filters were suitable for Pu-XANES measurements. However, the $\mathrm{Pu}$ concentrations on the clay fractions were typically too low for suitable XANES data acquisition. The differences in total $\mathrm{Pu}$ counts between the sediments in contact with the filters and the clay fractions from the sediments that were sampled at greater depths were often three orders of magnitude.

A table representing the Pu-XANES oxidation state results for the two filters and underlying sediment material is shown in Table 3. The values for $\mathrm{Pu}(\mathrm{III})$ and $\mathrm{Pu}(\mathrm{IV})$ are based on the assumption that: 1) only $\mathrm{Pu}(\mathrm{III})$ and $\mathrm{Pu}(\mathrm{IV})$ are present in the samples and 2) that the $\mathrm{Pu}(\mathrm{III})$ and $\mathrm{Pu}(\mathrm{IV})$ oxidation state standards provide an accurate estimation of $\mathrm{Pu}$-XANES edge energy calibration for our samples. The average oxidation state of $\mathrm{Pu}$ in the filter paper from the two lysimeters is somewhat related to the initial oxidation state of $\mathrm{Pu}$ added. For example, the average amount of $\mathrm{Pu}(\mathrm{III})$ on the filter paper that had $\mathrm{Pu}$ initially added as $\mathrm{Pu}(\mathrm{III})$ is higher than in the other filter paper which had Pu added in the tetravalent form.

The Pu-XANES spectra acquired for regions " $\mathrm{A}$ " and "C" on the sediment sample from Lysimeter \#9-Pu(NO 3$)_{4}$ in addition to XANES spectra for three Pu oxidation state standards are 
shown in Figure 9. The XANES data analyses are based on the half-height of the normalized absorption edge step for $\mathrm{Pu}$ at the $\mathrm{Pu} \mathrm{L}_{3}$ edge (Duff et al. 1999). The Pu-XANES spectrum taken from region " $\mathrm{A}$ " contained $86 \% \mathrm{Pu}(\mathrm{IV})$ with the remainder being $\mathrm{Pu}(\mathrm{III})$. The spectra taken from region "C" contained $45 \% \mathrm{Pu}(\mathrm{IV})$ and $55 \% \mathrm{Pu}(\mathrm{III})$. Calibration error estimates on these values are estimated to be $25 \%$. [Actual locations on the Lysimeter $\# 9-\mathrm{Pu}\left(\mathrm{NO}_{3}\right)_{4}$ sediment sample are shown in Figure 7-b; upper right image.]

The wet chemistry analyses of the Pu oxidation state distributions presented in Section 4.2 and those made by $\mathrm{Pu}-\mathrm{XANES}$ clearly indicate that essentially no $\mathrm{Pu}(\mathrm{V})$ or $\mathrm{Pu}(\mathrm{VI})$ existed in these systems. This is an important finding insofar that it provides two independent estimates of the $\mathrm{Pu}$ oxidation state distribution, and both estimates indicate that the $\mathrm{Pu}$ exists almost entirely in the reduced, less mobile form. The wet chemistry method indicated that $\mathrm{Pu}(\mathrm{V})$ and $\mathrm{Pu}(\mathrm{VI})$ accounted for $<5 \%$ of the Pu (Figure 4). Pu-XANES analyses did not detect any Pu(VI) and detected $\mathrm{Pu}(\mathrm{V})$ in only 1 of the 27 spectra collected (Table 3; the one spectrum was taken of the $\mathrm{PuCl}_{3}$ filter). One inconsistency between the two types of measurement was that the Pu-XANES estimated that more $\mathrm{Pu}$ existed in the +3 state than did the wet chemistry technique. As noted above, additional XANES spectra must be collected of appropriate $\mathrm{Pu}$ standards materials to verify the Pu distributions presented in Table 3. This inconsistency, although important for fully understanding $\mathrm{Pu}$ geochemistry, does not influence the proposed conceptual model of $\mathrm{Pu}$ geochemistry in the SRS subsurface (Kaplan 2004) because the proposed model pools $\mathrm{Pu}(\mathrm{III})$ and $\mathrm{Pu}(\mathrm{IV})$ together, treating them as one $\mathrm{Pu}$ species, distinct from the oxidized $\mathrm{Pu}, \mathrm{Pu}(\mathrm{V} / \mathrm{VI})$.

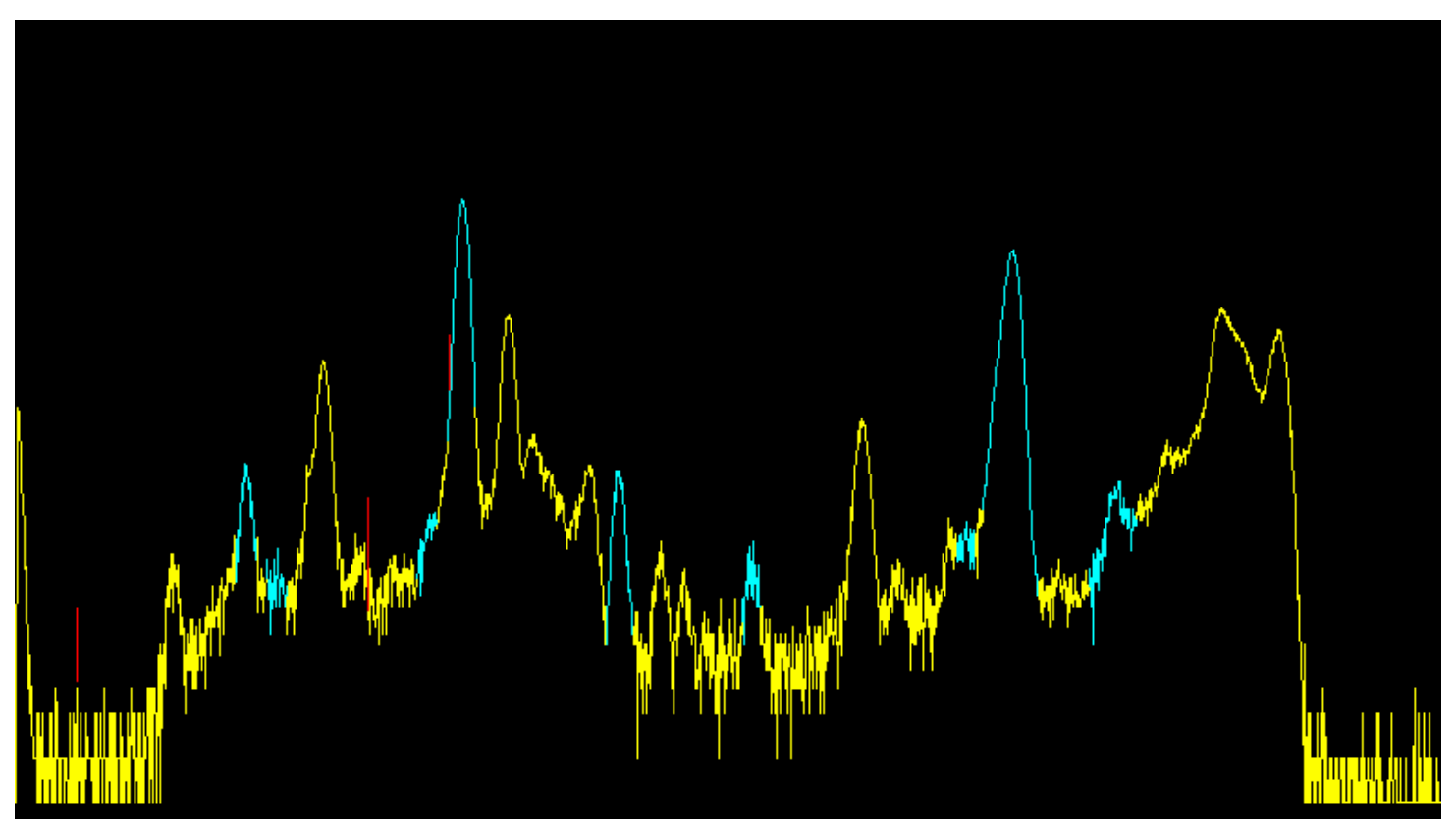

Figure 5. Microprobe-XRF spectrum taken at region " $A$ " on sediment from Lysimeter \#9$\mathrm{Pu}\left(\mathrm{NO}_{3}\right)_{4}$. This sediment sample was taken from where the $\mathrm{Pu}(\mathrm{IV})$-spiked filter made contact with the sediment. Elemental regions of interest (shown in blue) were selected for calcium, iron, manganese, zinc, lead, uranium, $\mathrm{Pu}$, and zirconium. 
WSRC-TR-2004-00493, REV. 0
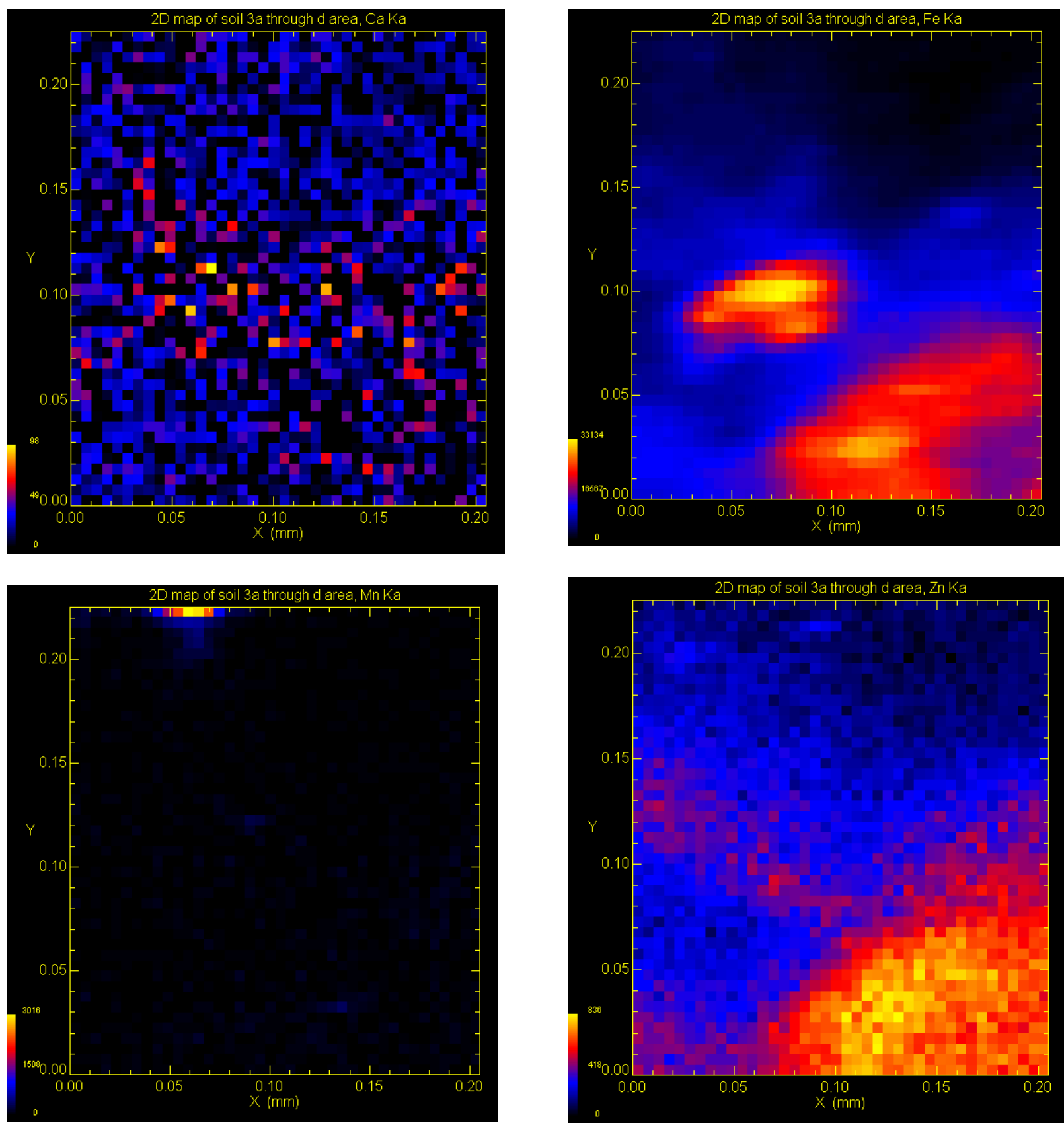

Figure 6. Micro-SXRF elemental map images of sediment next to the $\mathrm{Pu}(\mathrm{IV})$-spiked filter in $\mathrm{Pu}\left(\mathrm{NO}_{3}\right)_{4}$ lysimeter: (top left) calcium, (top right) iron, (bottom left) manganese, and (bottom right) zinc. Figures 7 and 8 include maps of other elements from the same sample location. 
WSRC-TR-2004-00493, REV. 0
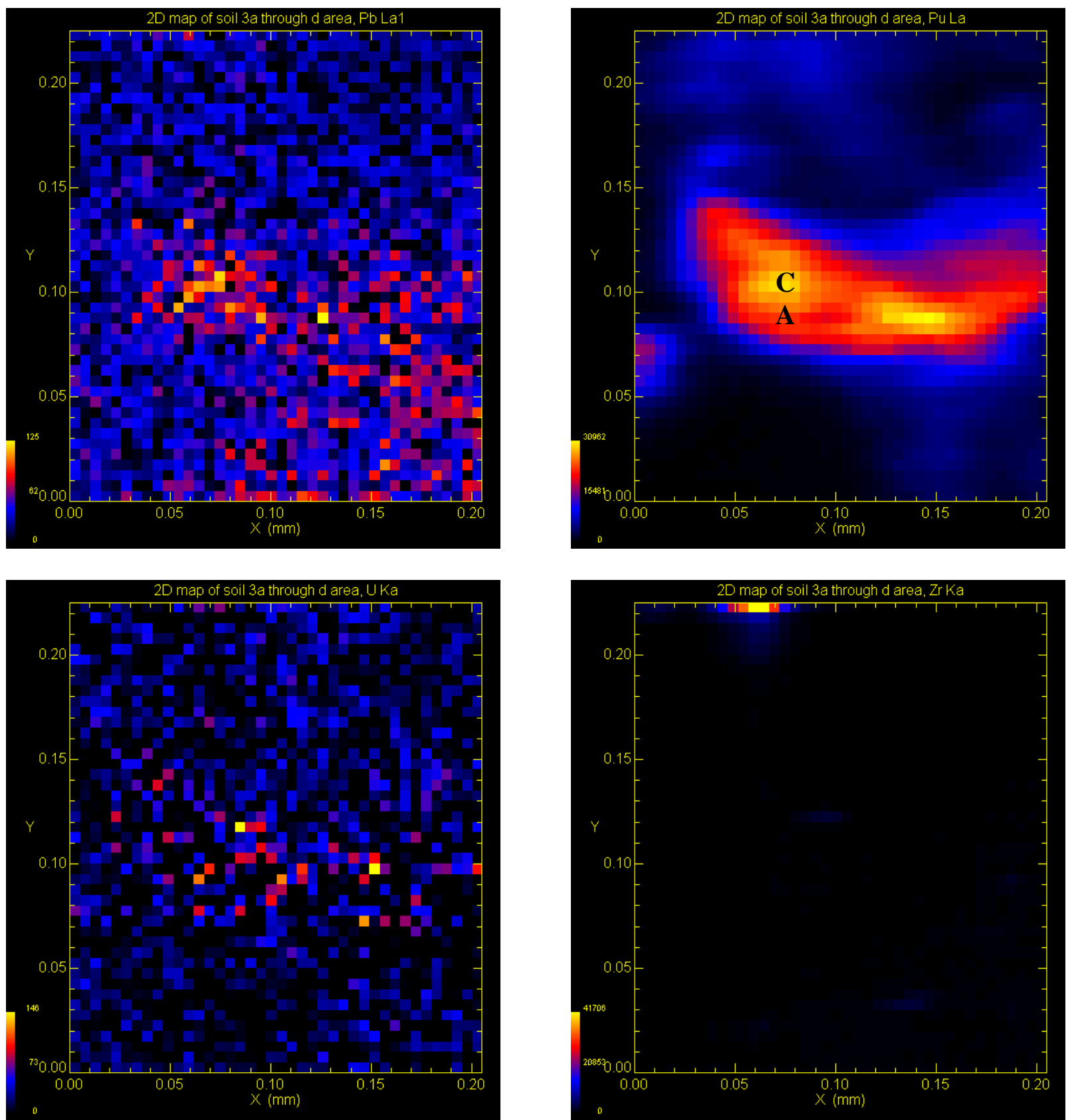

Figure 7. Micro-SXRF elemental map images of sediment next to the Pu(IV)-spiked filter in $\mathrm{Pu}\left(\mathrm{NO}_{3}\right)_{4}$ lysimeter: (top left) lead, (top right) plutonium, (bottom left) uranium, and (bottom right) zirconium. Several regions including those labeled as "A" and " $C$ " were examined using $\mathrm{Pu}$-XANES spectroscopic techniques. Figures 6 and 8 include maps of other elements from the same sample location. 


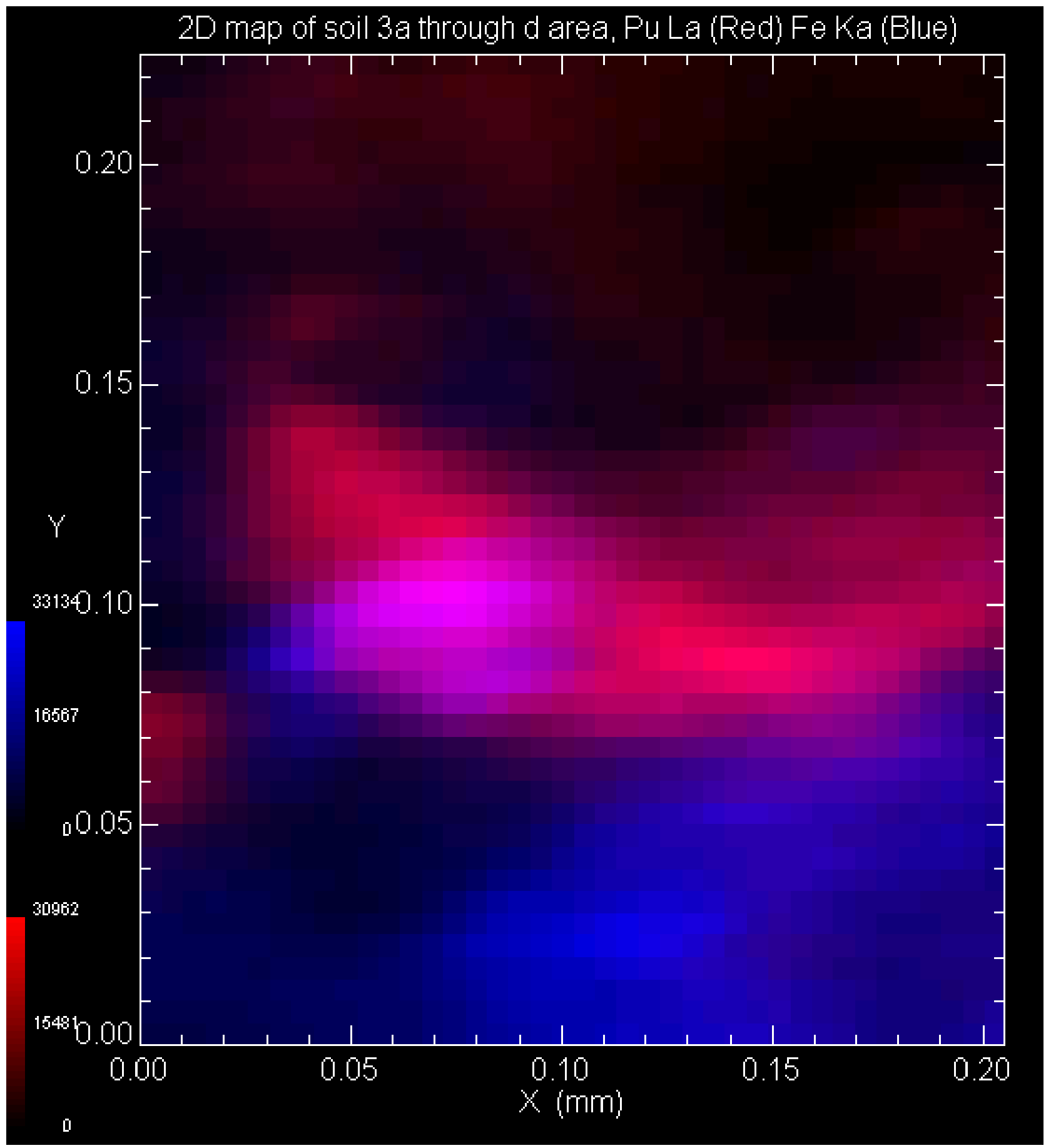

Figure 8. Correlation plot of microprobe-SXRF image of plutonium (red) and iron (blue) in sediment next to the $\mathrm{Pu}(\mathrm{IV})$-spiked filter in $\mathrm{Pu}\left(\mathrm{NO}_{3}\right)_{4}$ lysimeter; the highest plutonium-iron correlations are represented in pink. Figures 6 and 7 include maps of other elements from the same sample location. 
Table 3. The calculated average distribution for $\mathrm{Pu}(\mathrm{III})$ and $\mathrm{Pu}(\mathrm{IV})$ in the lysimeter samples based on edge energy in comparison to spectra for $\mathrm{Pu}(\mathrm{IV})$ in $\mathrm{PuO}_{2}(\mathrm{~s})$ and $\mathrm{Pu}(\mathrm{III})$ in $\mathrm{PuBr}_{3}(\mathrm{~s})$ ( $^{\text {(a) }}$

\begin{tabular}{|c|c|c|c|}
\hline $\begin{array}{l}\text { Lysimeter } \\
\text { Sample }\end{array}$ & $\begin{array}{c}\text { Average \% Pu(IV) } \\
\text { with Sample }^{(b)} \\
\text { Standard Deviation }^{(b)}\end{array}$ & $\begin{array}{c}\text { Average \% Pu(III) } \\
\text { with Sample }^{(b)} \\
\text { Standard Deviation }^{(b)}\end{array}$ & $\begin{array}{c}\text { Number of } \\
\text { XANES } \\
\text { Measurements }\end{array}$ \\
\hline $\begin{array}{l}\text { Filter paper from lysimeter } \# 9 \\
{[\mathrm{Pu} \text { originally added as } \mathrm{Pu}(\mathrm{IV})]}\end{array}$ & $77 \pm 17$ & $21 \pm 17$ & 7 \\
\hline $\begin{array}{l}\text { Filter paper from lysimeter } \# 12 \\
{[\mathrm{Pu} \text { originally added as } \mathrm{Pu}(\mathrm{III})]}\end{array}$ & $48 \pm 3$ & $52 \pm 3$ & 3 \\
\hline $\begin{array}{l}\text { Sediment in contact with filter } \\
\text { from lysimeter } \# 9-\mathrm{Pu}\left(\mathrm{NO}_{3}\right)_{4}\end{array}$ & $63 \pm 18$ & $38 \pm 18$ & 10 \\
\hline $\begin{array}{l}\text { Sediment in contact with filter } \\
\text { from lysimeter } \# 12-\mathrm{PuCl}_{3}{ }^{(\mathrm{c})}\end{array}$ & $65 \pm 17$ & $35 \pm 17$ & 7 \\
\hline \multicolumn{4}{|c|}{$\begin{array}{l}\text { (a) The use of } \mathrm{Pu}(\mathrm{IV}) \text {-nitrate and } \mathrm{Pu}(\mathrm{III}) \text {-chloride oxidation standards is recommended because it is } \\
\text { possible that the XANES absorption edge can be influenced by the local environment as presented } \\
\text { by Conradson et al. (2004). These analyses will need to be revisited once additional spectra are } \\
\text { acquired for these other Pu standards. It is possible that these oxidation state values below could be } \\
\text { shifted linearly to a more oxidized distribution of } \mathrm{Pu}[\mathrm{i} \text {.e, more } \mathrm{Pu}(\mathrm{IV}) \text { rich] than what is shown if } \\
\text { the } \mathrm{Pu} \text {-XANES results with other oxidation state standards indicate this to be the case. } \\
\text { (b) Only } \mathrm{Pu}(\mathrm{III}) \text { and } \mathrm{Pu}(\mathrm{IV}) \text { species were assumed to be present for these calculations. } \\
\text { (c) One of the XANES analyses for this sample showed } 58 \% \mathrm{Pu}(\mathrm{IV}) \text { and } 42 \% \mathrm{Pu}(\mathrm{V}) \text { and this } \\
\text { measurement assumed that only } \mathrm{Pu}(\mathrm{IV}) \text { and } \mathrm{Pu}(\mathrm{V}) \text { were present in this sample. }\end{array}$} \\
\hline
\end{tabular}


WSRC-TR-2004-00493, REV. 0

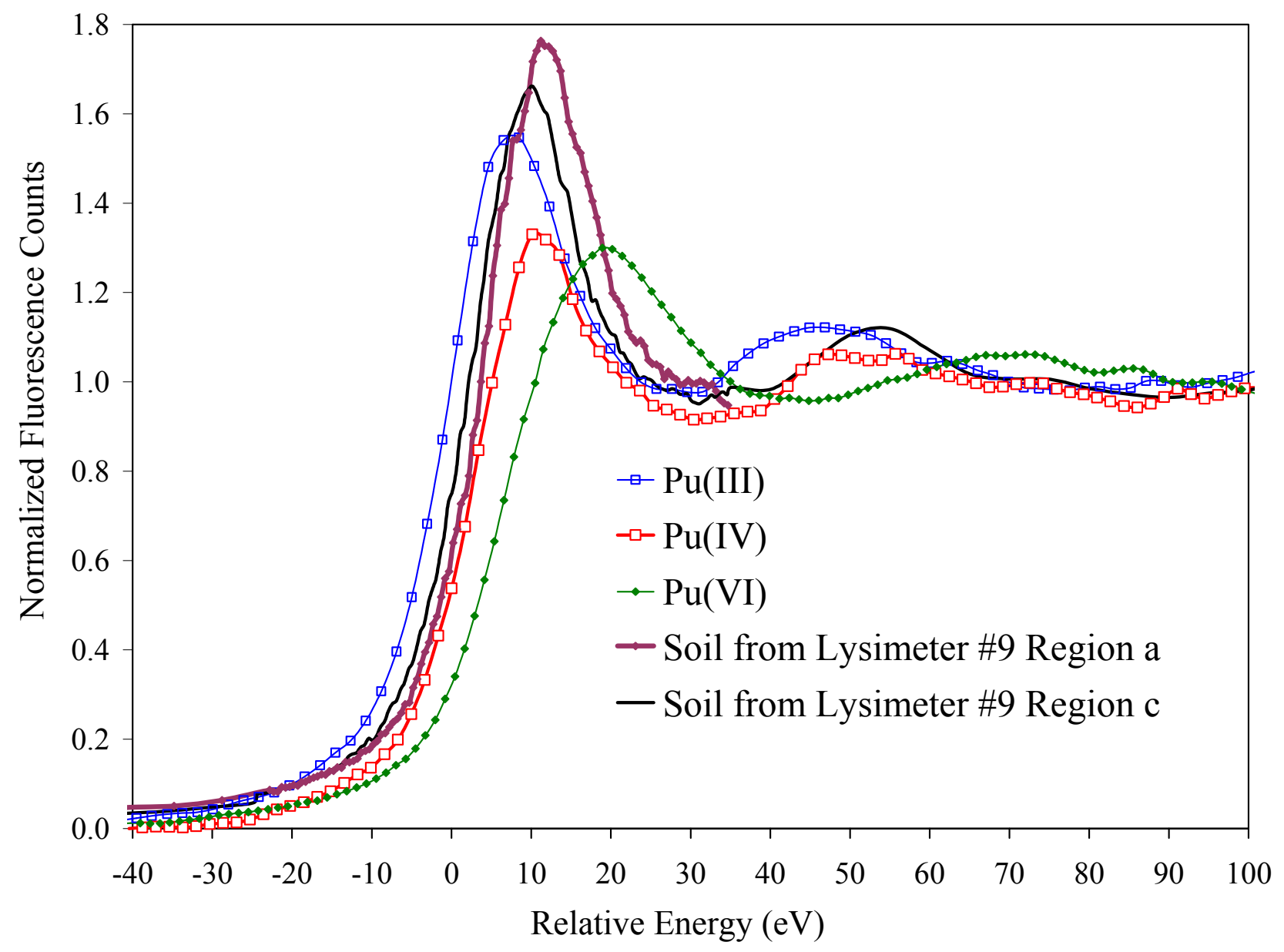

Figure 9. The $\mathrm{Pu}-\mathrm{XANES}$ spectra for the standards $[\mathrm{Pu}(\mathrm{IV})$ and $(\mathrm{VI})]$ and regions " $\mathrm{C}$ " and " $\mathrm{A}$ " on the sediment taken next to the $\mathrm{Pu}(\mathrm{IV})$-spiked filter in Lysimeter \#9-Pu( $\left.\mathrm{NO}_{3}\right)_{4}$. The spectra demonstrate the edge energy shift with oxidation state at the half height of the edge step (i.e., when Normalized Fluorescence Counts $=0.5$ ). The average edge energy for sediment from Lysimeter \#9$\mathrm{Pu}\left(\mathrm{NO}_{3}\right)_{4}$ (region $\mathrm{C}$ ) is roughly midway between $\mathrm{Pu}(\mathrm{III})$ and $\mathrm{Pu}(\mathrm{IV})$ which, based on relative edge energy, would be consistent with a mixed $\mathrm{Pu}(\mathrm{III} / \mathrm{IV})$ species. 
WSRC-TR-2004-00493, REV. 0

\subsection{PLUTONIUM CONCENTRATIONS AS A FUNCTION OF DEPTH IN THE LYSIMETERS}

Total $\mathrm{Pu}$ concentration data from the $\mathrm{PuO}_{2}\left(\mathrm{NO}_{3}\right)_{2}$ and $\mathrm{Pu}\left(\mathrm{NO}_{3}\right)_{4}$ have previously been reported (Kaplan et al. 2003). This data will be included in this study to permit comparison between all four lysimeters characterized to date.

\subsubsection{Comparison of Sediment Pu Concentration Distributions in Pu(III) and Pu(IV) Treated Lysimeter Cores}

Total $\mathrm{Pu}$ concentration depth-profiles in the two $\mathrm{Pu}(\mathrm{IV})$ lysimeters and one $\mathrm{Pu}(\mathrm{III})$ lysimeter were nearly identical for the surface $12 \mathrm{~cm}$ (Figure 10). This is consistent of the conclusion made from the wet-chemistry analyses that the sediment $\mathrm{Pu}$ oxidation state distributions in these three lysimeters were very similar and that the mode of transport is also very similar (Figure 3 ). The striking similarity of these data also suggests that the data are reproducible, which in turn provides additional reassurance of the data quality.

Below the 12-cm depth, it is not clear why the total $\mathrm{Pu}$ concentrations in the $\mathrm{PuCl}_{3}$ lysimeter increased as depth increased, unlike the two other lysimeters. The cause for this unexpected result is not known. 


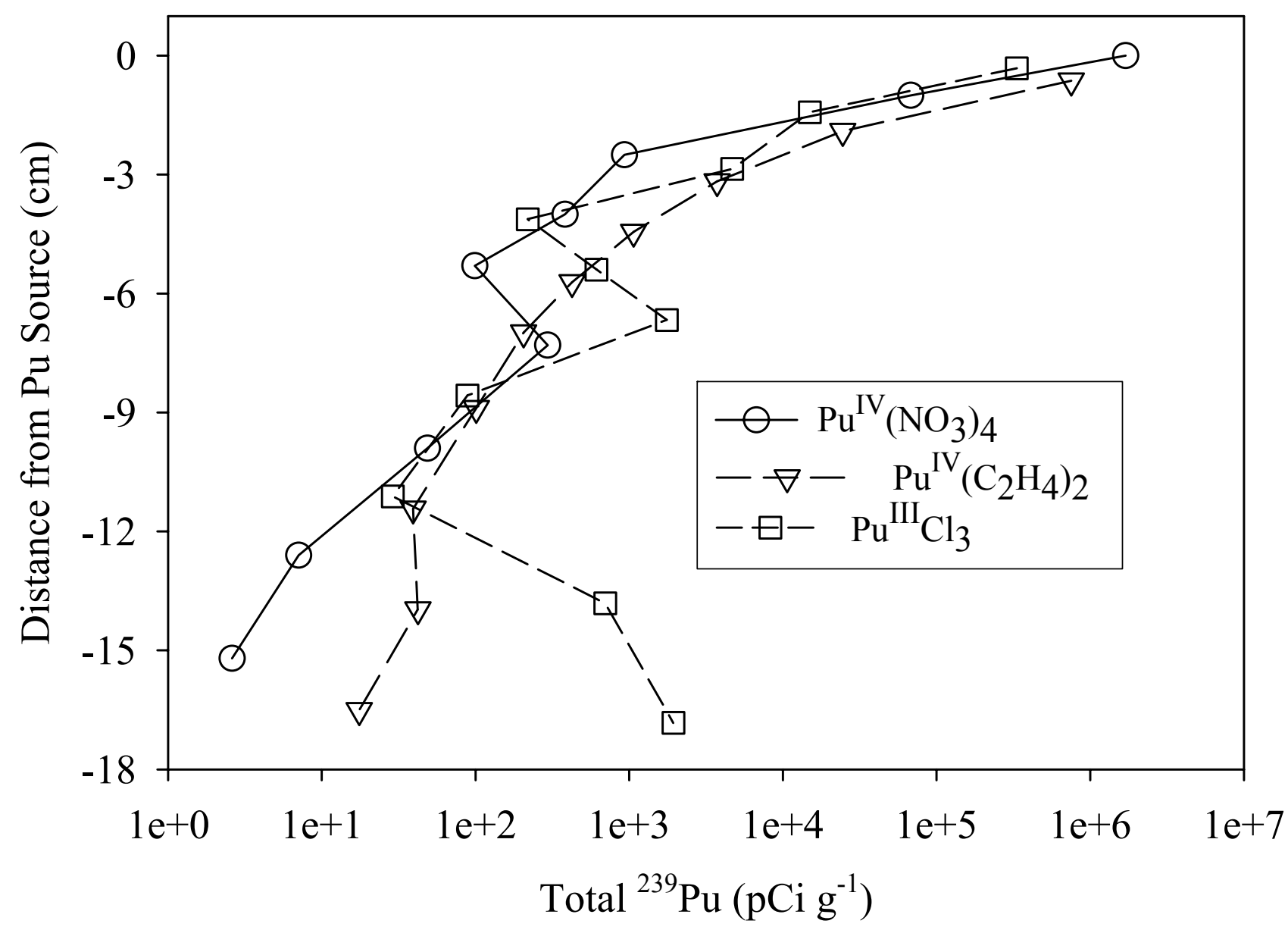

Figure 10. Total sediment $\mathrm{Pu}$ concentrations in $\mathrm{Pu}(\mathrm{III})$ and $\mathrm{Pu}(\mathrm{IV})$ lysimeters after 11 years.

\subsubsection{Comparison of Sediment Pu Concentration Distributions in Pu(IV) and Pu(VI) Treated Lysimeter Cores}

A striking difference was observed between the concentration profiles of the $\mathrm{Pu}(\mathrm{VI})$ lysimeter and those of the $\mathrm{Pu}(\mathrm{III})$ and $\mathrm{Pu}(\mathrm{IV})$ lysimeters (Figure 11). The $\mathrm{Pu}(\mathrm{VI})$ profile was measured after the lysimeter had been in the field for only two years, whereas the other profiles were measured after the lysimeters had been in the field for 11 years. The $\mathrm{Pu}$ in the $\mathrm{Pu}(\mathrm{VI})$ lysimeter had moved appreciably faster than in the other lysimeters: $\mathrm{Pu}$ traveled on average $12.5 \mathrm{~cm} / \mathrm{yr}$ in the $\mathrm{Pu}(\mathrm{VI})$ lysimeter, whereas $\mathrm{Pu}$ traveled $0.9 \mathrm{~cm} / \mathrm{yr}$ in the $\mathrm{Pu}(\mathrm{III})$ and $\mathrm{Pu}(\mathrm{IV})$ lysimeters. Modeling of the $\mathrm{Pu}\left(\mathrm{NO}_{3}\right)_{4}$ and the $\mathrm{Pu}^{\mathrm{VI}} \mathrm{O}_{2}\left(\mathrm{NO}_{3}\right)_{4}$ lysimeters has previously been reported in Kaplan et al. (2003). The most important conclusions from the modeling are that:

- In order to capture the shape of the Pu depth profile data in the $\mathrm{Pu}^{\mathrm{IV}}\left(\mathrm{NO}_{3}\right)_{4}$ lysimeter, a reduction and an oxidation kinetic term had to be included in the simulation (Figure 12). The reduction rate was five orders of magnitude greater than the oxidation rate; consistent in difference (but not magnitude) as laboratory measurements of these two reaction rates. 
- In order to capture the shape of the Pu depth profile data in the $\mathrm{Pu}^{\mathrm{VI}} \mathrm{O}_{2}\left(\mathrm{NO}_{3}\right)_{2}$ lysimeter, a reduction, but not an oxidation kinetic term had to be included in the simulation (Figure 13). Inclusion of an oxidation term either did not change or made predicted values worse.

One possible explanation for why an oxidation term improved the model fit of the $\mathrm{Pu}(\mathrm{IV})$ data and not the $\mathrm{Pu}(\mathrm{VI})$ data is because the latter was conducted for only two years, and the relatively slow oxidation rate had not had sufficient time to manifest itself. Whereas in the three $\mathrm{Pu}(\mathrm{III})$ or $\mathrm{Pu}(\mathrm{IV})$ lysimeters, the 11 year transport period was sufficiently long to permit the slow oxidation reaction to manifest itself in the $\mathrm{Pu}$ concentration depth profile data.

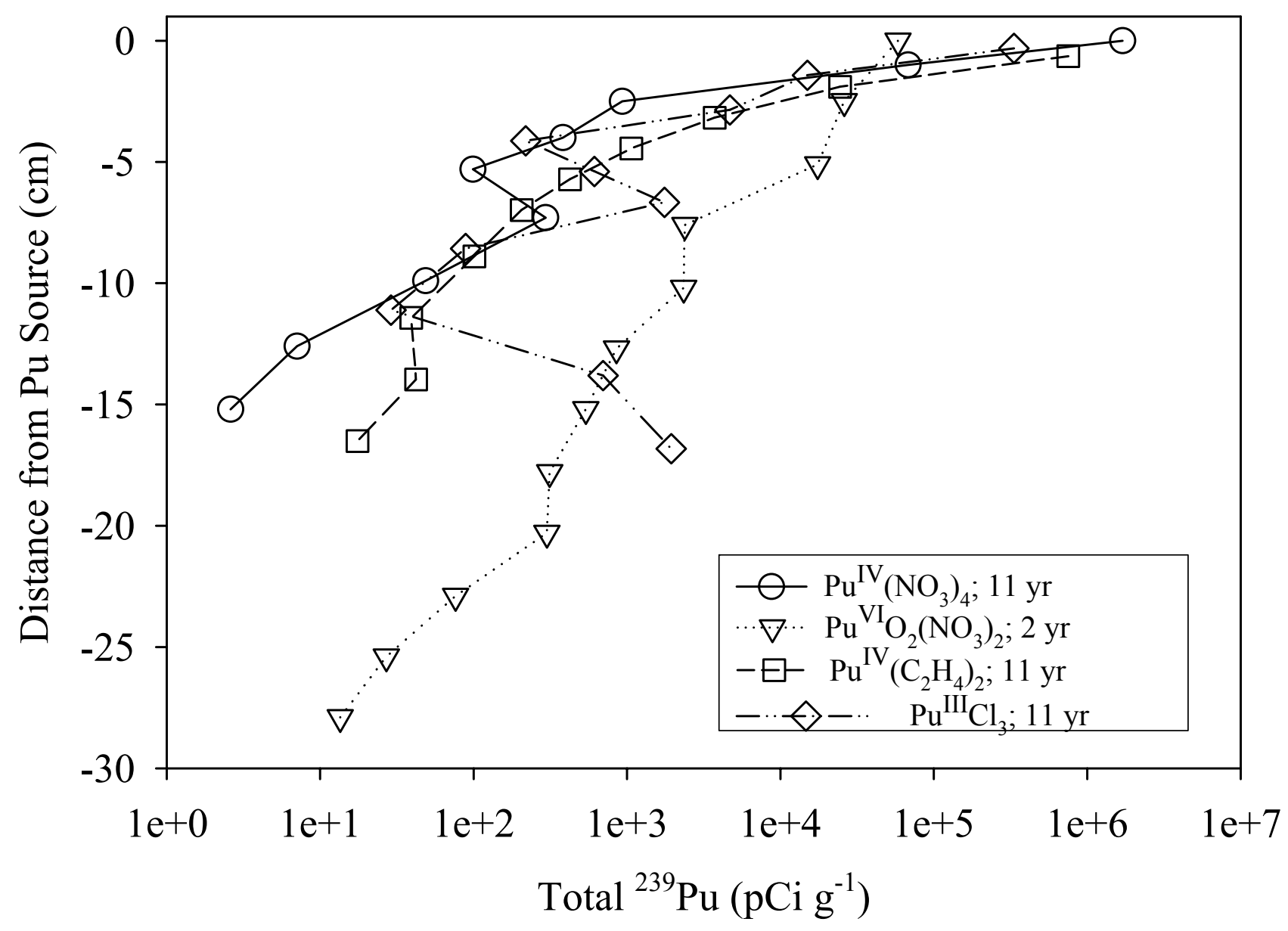

Figure 11. Total $\mathrm{Pu}$ concentration of four lysimeters after two or 11 years. 
WSRC-TR-2004-00493, REV. 0

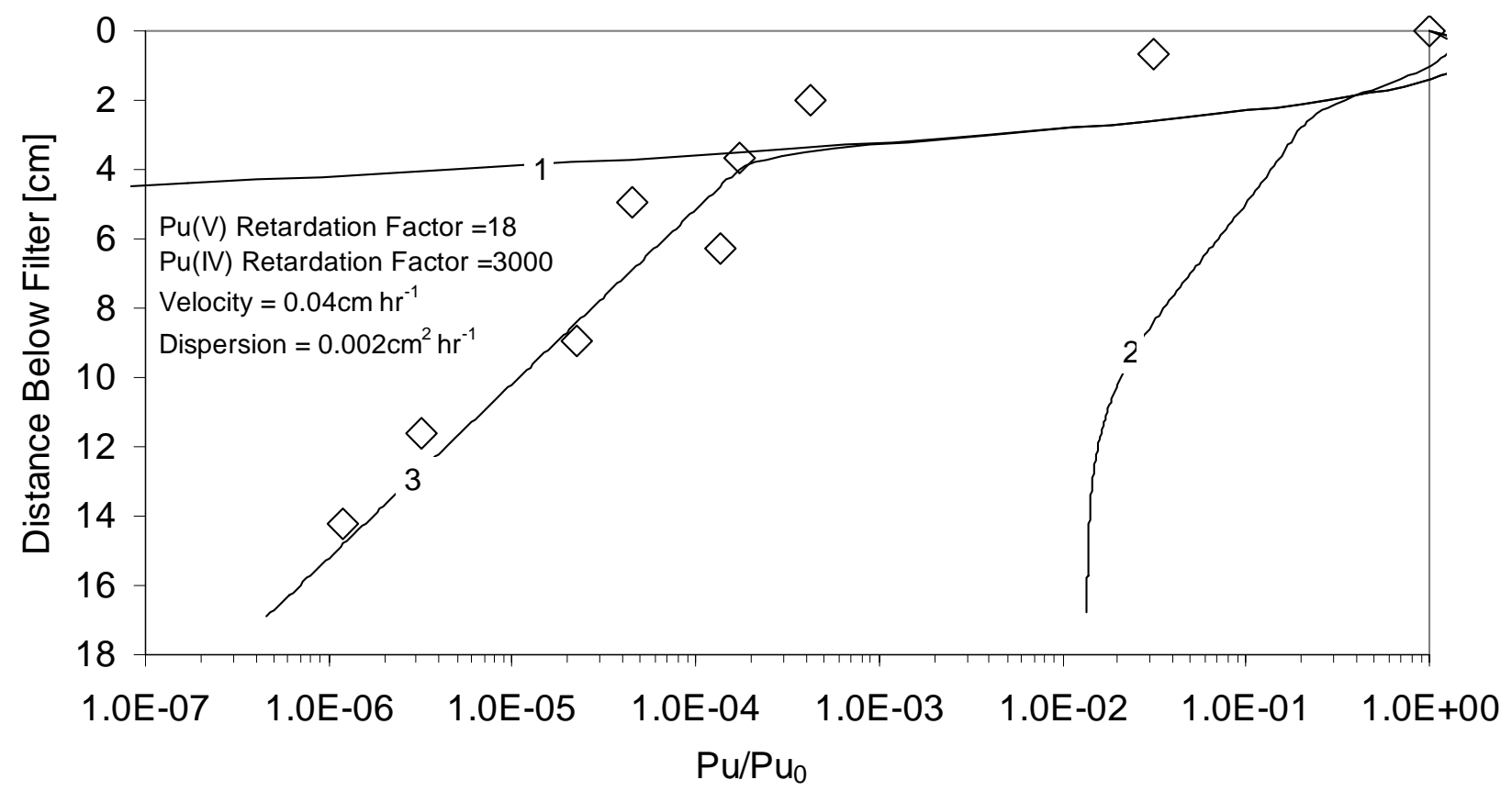

Figure 12. Normalized total $\mathrm{Pu}$ sediment concentrations $\left(\mathrm{Pu} / \mathrm{Pu}_{0}\right)$ in the $\mathrm{Pu}^{\mathrm{IV}}\left(\mathrm{NO}_{3}\right)_{4}$ amended lysimeter. Diamond symbols represent measured values. Simulation input values ( $k o$ and $k r$ are the first-order rate constants for $\mathrm{Pu}(\mathrm{IV})$ oxidation and $\mathrm{Pu}(\mathrm{V} / \mathrm{VI})$ reduction, respectively): (1) $k o=0 \mathrm{~h}^{-1}, k r$ $=0 \mathrm{~h}^{-1}$; (2) $k o=1 \mathrm{e}-5 \mathrm{~h}^{-1}, k r=0 \mathrm{~h}^{-1}$; (3) $k o=1 \mathrm{e}-8 \mathrm{~h}^{-1}, k r=1.2 \mathrm{e}-3 \mathrm{~h}^{-1}$. A reduction and oxidation term was included in simulation (3). 
WSRC-TR-2004-00493, REV. 0

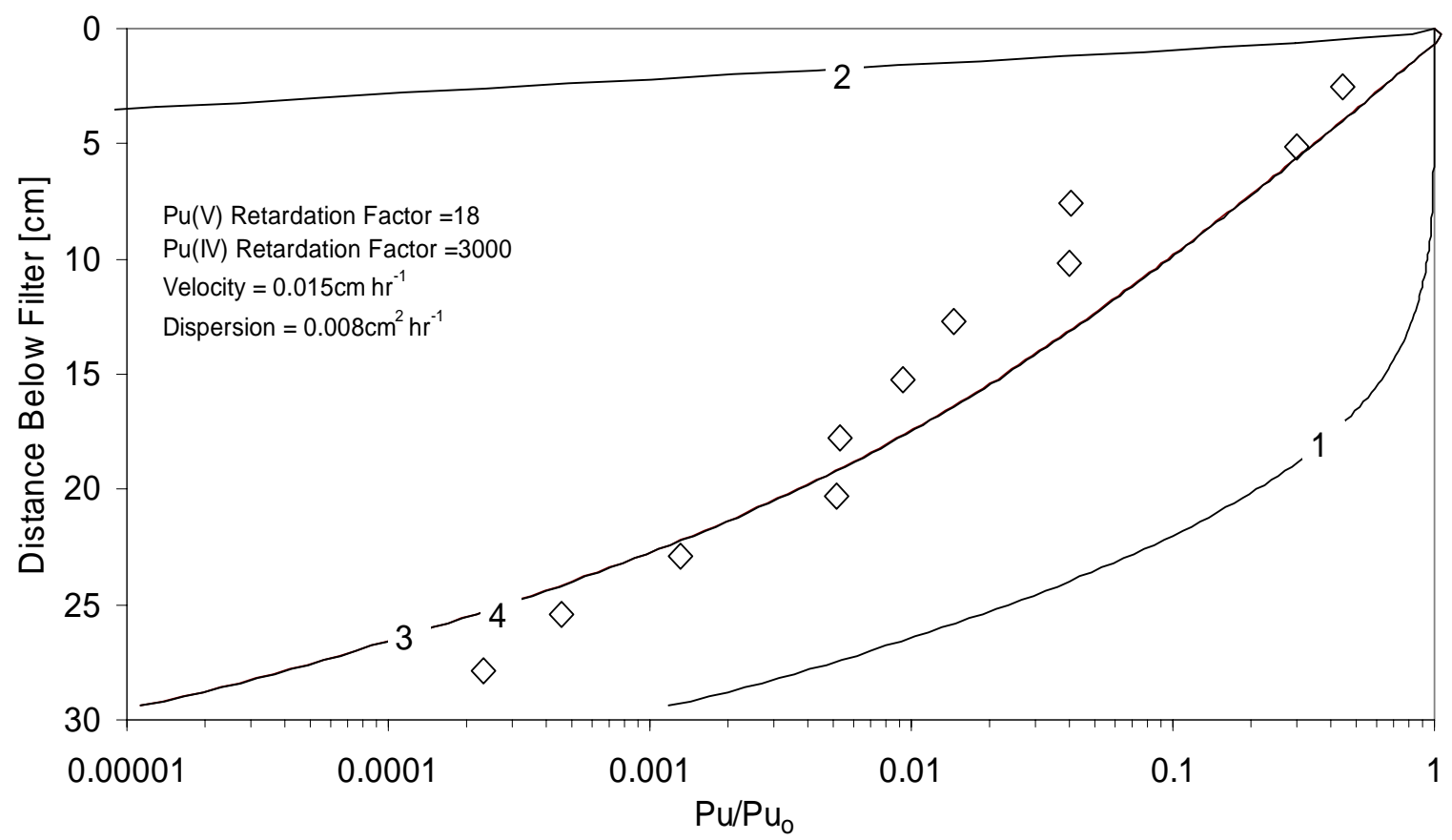

Figure 13. Normalized total $\mathrm{Pu}$ sediment concentrations $\left(\mathrm{Pu} / \mathrm{Pu}_{0}\right)$ in the $\mathrm{Pu}^{\mathrm{VI}} \mathrm{O}_{2}\left(\mathrm{NO}_{3}\right)_{2}$-amended lysimeter. Diamond symbols represent measured values. Simulation input values ( $k o$ and $k r$ are the first-order rate constants for $\mathrm{Pu}(\mathrm{IV})$ oxidation and $\mathrm{Pu}(\mathrm{V} / \mathrm{VI})$ reduction, respectively): (1) $k o=0 \mathrm{hr}^{-1}$, $k r=0 \mathrm{hr}^{-1}$; (2) $k o=0 \mathrm{hr}^{-1}, k r=1 \mathrm{e}-5 \mathrm{hr}^{-1}$; (3) $k o=0 \mathrm{hr}^{-1}, k r=2.0 \mathrm{e}-4 \mathrm{hr}^{-1}$; and (4) $k o=1.0 \mathrm{e}-6 \mathrm{hr}^{-1}, k r=$ $2.0 \mathrm{e}-4 \mathrm{hr}^{-1}$. There was near identical simulations with or without an oxidation term, simulation 4 and 3 , respectively. 


\subsection{CONCLUSIONS}

Results from this work were entirely consistent with previous findings on the geochemistry of $\mathrm{Pu}$ in SRS sediments, and as such provide additional technical support for the conceptual $\mathrm{Pu}$ geochemical model put forth by Kaplan (2004). When lysimeters containing $\mathrm{Pu}(\mathrm{III})$ or $\mathrm{Pu}(\mathrm{IV})$ were left exposed to the natural environment for 11 years, $>95 \%$ of the sediment-bound Pu existed as $\mathrm{Pu}(\mathrm{IV})$. In these lysimeters, $\mathrm{Pu}$ sediment concentrations decreased on average an order-of-magnitude per centimeter for the first $5 \mathrm{~cm}$ below the source, a rapid rate of contaminant retardation. When $\mathrm{Pu}(\mathrm{VI})$, a highly mobile but chemically unstable oxidation state of $\mathrm{Pu}$, was added to the lysimeters, Pu moved faster than it had in the other lysimeters: Pu moving on average $12.5 \mathrm{~cm} / \mathrm{yr}$ in the Pu(VI) lysimeter, compared to $0.9 \mathrm{~cm} / \mathrm{yr}$ in the $\mathrm{Pu}(\mathrm{III})$ and $\mathrm{Pu}(\mathrm{IV})$ lysimeters. Importantly, transport modeling of the data clearly suggested that reduction of the original $\mathrm{Pu}(\mathrm{VI})$ occurred, thus most of the transport of the $\mathrm{Pu}$ in the lysimeter would have occurred during the early portion of the study, prior to the sediment-induced reduction of $\mathrm{Pu}(\mathrm{VI})$. When $\mathrm{Pu}(\mathrm{V})$ was added to the lysimeter sediment in a laboratory study, the $\mathrm{Pu}(\mathrm{V})$ quickly reduced to $\mathrm{Pu}(\mathrm{IV})$ within a couple days on the soil and remained as $\mathrm{Pu}(\mathrm{V})$ in solution. These data together with those from previous reports for this project show that the majority of $\mathrm{Pu}$, irrespective of the form it is introduced into SRS sediments, naturally tends to convert to the least-mobile oxidation state, the +4 oxidation state. 


\subsection{REFERENCES}

Bertrand, P.A., and G. R. Choppin. 1982. Separation of actinides in different oxidation states by solvent extraction. Radiochim. Acta. 31:135-137.

Bertsch, P. M., Hunter, D. B., Sutton, S. R., Bajt, S. and Rivers, M. L. (1994). In situ chemical speciation of uranium in soils and sediment by micro X-ray absorption spectroscopy. Environ. Sci. Technol., 28, 80-984.

Collard, L. B., and R. A. Hiergesell. 2004. Special Analysis: 2004 General Revision of Slit and Engineered Trench Limits. WSRC-TR-2004-00300. Westinghouse Savannah River Company, Aiken, SC.

Conradson, S. D. et al. (2004). Higher order speciation effects for $\mathrm{Pu} \mathrm{L}_{3} \mathrm{X}$-ray absorption near edge structure spectra. Inorg. Chem. 43, 116-131.

Denham, M., J. R. Kastner, K. M. Jerome, J. Santo Domingo, B. B. Looney, M. M. Franck, and J. V. Noonkester. 1999. Effects of Fenton's Reagent on Aquifer Geochemistry and Microbiology at the A/M Area, Savannah River Site, WSRC-TR-99-00428. Westinghouse Savannah River Company, Aiken, SC.

Duff, M. C., Newville, M., Hunter, D. B., Bertsch, P. M. Sutton, S. R., Triay, I. R., Vaniman, D. T., Eng'P. and Rivers, M. L. (1998). Micro-XAS studies with sorbed plutonium on tuff. J. Synchrotron. Radiation 6, 350-352.

Duff, M. C., Hunter, D. B., Triay, I. R., Bertsch, P. M., Reed, D. T., Sutton, S. R., Shea-McCarthy, G., Kitten, J., Eng, R., Chipera, S. J. and Vaniman, D. T. (1999). Mineral associations and average oxidation states of sorbed Pu on tuff. Environ. Sci. Technol. 33, 2163-2169.

Duff, M. C., Newville, M., Hunter, D. B., Sutton, S. R., Triay, I. R., Vaniman, D. T., Bertsch. P. M., Eng, P. and Rivers,' M. L. (2001). APS Forefront, Advanced Photon Source, Argonne National Laboratory. 1: 18-21.

Eng, P. J., Rivers, M. L., Yang, B. X. and Schildkamp, W. (1995). Microfocusing 4-keV to 65-keV X-rays with bent Kirkpatrick-Baez mirrors. Proc. SPIE 2516, 41-51.

Fjeld, R. A., S. M. Serkiz, P. L. McGinnis, A. Elci, and D. I. Kaplan. 2004. Modeling the effect of surface-mediated reduction of $\mathrm{Pu}(\mathrm{V})$ to $\mathrm{Pu}(\mathrm{IV})$ on plutonium transport behavior. J. Contam. Hydrol. 67(1-4):79-94.

Flach, G. P., and R. A. Hiergesell. 2004. Special Analysis: Revision of Intermediate Level Vault Disposal Limits. WSRC-TR-2004-00346. Westinghouse Savannah River Company, Aiken, SC.

Holcom, H. P. 1980. Source Preparation for Mini-Lysimeters. Memorandum to E. J. Lukosius, June 19, 1980. Westinghouse Savannah River Company, Aiken, SC. 
Haschke, J.M., T.H. Allen, and L.A. Morales. 2000. Reaction of plutonium dioxide with water: formation and properties of $\mathrm{PuO}_{2+\mathrm{x}}$. Science, 287:285-287.

Kaplan, D. I. 2004. Recommended Pu Geochemical Input Values for the Special Analysis of the Slit and Engineered Trenches. WSRC-RP-2004-00243, Rev 0. Westinghouse Savannah River Company, Aiken, SC.

Kaplan, D. I., P. M. Bertsch, D. C. Adriano, and K. A. Orlandini. 1994. Actinide association with groundwater colloids as a function of distance from a point source. Radiochimica Acta 66/67:181187.

Kaplan, D. I., D. I. Demirkanli, R. A. Fjeld, F. Molz, B. Powell, D. Reid, S. M. Serkiz. 2003. Plutonium Transport Through Lysimeters Exposed to Natural Weather Conditions for Two to Twelve Years. WSRC-TR-2003-00300, Rev. 0. Westinghouse Savannah River Company, Aiken, SC.

Kaplan, D. I., B. A. Powell, D. I. Demirkanli, R. A. Fjeld, F. J. Molz, S. M. Serkiz, J. T. Coates. 2004. Enhanced plutonium mobility during long-term transport through an unsaturated subsurface environment. Environ. Sci. Technol. (In press).

Kaplan, D. I., and E. Wilhite. 2001. Discovery of New Plutonium Chemistry and Its Potential Effect on LLW Disposal at SRS WSRC-RP-2000-00980. Westinghouse Savannah River Company, Aiken, $\mathrm{SC}$.

Keeney-Kennicutt, W. L., and J. W. Morse. 1985. The redox chemistry of $\mathrm{Pu}(\mathrm{V}) \mathrm{O}_{2}{ }^{+}$interaction with common mineral surfaces in dilute solutions and seawater. Geochim. Cosmochim. 49:2577-2588.

Kobashi, A. and G. R. Choppin, and J. W. Morse. 1988. A study of techniques for separating plutonium in different oxidation states. Radiochim. Acta. 43:211-215.

Morgenstern, A., and G. R. Choppin. 2002. Kinetics of the oxidation of Pu(IV) by manganese oxide. Radiochim. Acta. 90:69-74.

Neu, M. P., D. C. Hoffman, K. E. Roberts, H. Nitsche, and R. J. Silva. 1994. Comparison of chemical extractions and laser photoacoustic spectroscopy for determination of plutonium species in nearneutral carbonate solutions. Radiochim. Acta, 66:265-272.

Powell, B. A., R. A. Fjeld, D. I. Kaplan, S. M. Serkiz, and J. T Coates. 2004. Pu(V)O ${ }_{2}^{+}$interactions with synthetic magnetite $\left(\mathrm{Fe}_{3} \mathrm{O}_{4}\right)$. Environ. Sci. Technol., (In press).

Schulte, E. E., D. Kaufman, J. B. Peter. 1991. Measurement of organic carbon in soils. Commun. Soil Sci. Plant Anal. 22:159-168.

Sparks, D. L. Ed. 1996. Methods of Soil Analysis, Part 3, Chemical Methods; Soil Science Society of America: Madison, WI.

U.S. DOE. 1999a. Radioactive Waste Management, Order 435.1, U. S. Department of Energy. 
U.S. DOE. 1999b. Maintenance Guide for U.S. Department of Energy Low-Level Waste Disposal Facility Performance Assessments and Composite Analyses, U. S. Department of Energy.

U.S. DOE. 1999c.Disposal Authorization Statement for the Department of Energy Savannah River Site E-Area Vaults and Saltstone Disposal Facilities, U. S. Department of Energy.

WSRC. 1977. Composite Analysis E-Area Vaults and Saltstone Disposal Facilities, WSRC-RP-97311, Rev. 0, Savannah River Laboratory, Westinghouse Savannah River Company, Aiken, SC.

WSRC. 2000. Radiological Performance Assessment for the E-Area Vaults Disposal Facility. WSRC-RP-94-218, Rev. 1. Savannah River Laboratory, Westinghouse Savannah River Company, Aiken, SC.

Yang, B. X., Rivers, M. L., Schildkamp, W. and Eng, P. (1995). GEOCARS micro-focusing Kirkpatrick-Baez mirror bender development. Rev. Sci. Instrum. 66, 2278. 
WSRC-TR-2004-00493, REV. 0

7.0 APPENDIX A: DETAILED DESCRIPTION OF MATERIALS AND METHODS 


\subsection{MATERIALS AND METHODS FOR RECOVERING DEPTH-DISCRETE SAMPLES FROM THE MINI-LYSIMETER SEDIMENT M-7 CORE CONTAINING PU(C $\left.\mathrm{C}_{2} \mathrm{O}_{4}\right)_{2}$}

1. Conduct of Operations' R\&D Hazards Screening Checklist is located in lab notebook: wsrc-nb2001-00133, page 114.

2. Record all notes on column label into lab notebook.

3. Tamped sediment in column so that sediment is compacted at the bottom.

4. Measured total length of soil column is between 16.875 and 17.875 in (avg $=17.375$ inches).

5. Cut column at $\sim 7$ and $\sim 14$ inches from bottom.

6. Extruded sediment using ELE International Sample Ejector in $1 / 2$ - and 1-inch sections in the order shown in Table 1.

7. Sample ID\# 700, $14-17.375$ inches from bottom, will be collected by digging out sediment from the $14-30$ inch section of tube. We may attempt to further divide this section into $15-16$ and $16-17.375$ inches.

8. Place sediment in plastic weighing boats and then place the sediment-holding weighing boats in zip-locked bags.

9. Submitted $\sim 3$-g air-dried sample to ADS for

- Sodium-Peroxide Fusion Digestion and Nitric Acid Uptake

- $\mathrm{Pu}-239 / \mathrm{Pu}-238$ concentrations of total digestion (Check with Dave Diprete) 
WSRC-TR-2004-00493, REV. 0

Table 1. Actual Sample Collection Order and Depth.

\begin{tabular}{|c|c|c|c|c|c|c|}
\hline ID & $\begin{array}{l}\text { Sample } \\
\text { Collection } \\
\text { Order }\end{array}$ & Tube Segment & $\begin{array}{l}\text { Distance from } \\
\text { Bottom, Slice Bottom }\end{array}$ & $\begin{array}{c}\text { Distance from } \\
\text { Bottom, Slice } \\
\text { Top } \\
\end{array}$ & $\begin{array}{c}\text { Slice } \\
\text { Thickness }\end{array}$ & Observation \\
\hline & & (in) & (in) & (in) & (in) & \\
\hline 700 & 6 & 0 to 6.5 & 0 & 1 & 1 & moist \\
\hline 701 & 7 & 0 to 6.5 & 1 & 2 & 1 & moist \\
\hline 702 & 8 & 0 to 6.5 & 2 & 3 & 1 & moist \\
\hline 703 & 9 & 0 to 6.5 & 3 & 4 & 1 & moist \\
\hline 704 & 10 & 0 to 6.5 & 4 & 4.5 & 0.5 & moist \\
\hline 705 & 11 & 0 to 6.5 & 4.5 & 5 & 0.5 & moist \\
\hline 706 & 12 & 0 to 6.5 & 5 & 5.5 & 0.5 & moist \\
\hline 707 & 13 & 0 to 6.5 & 5.5 & 6 & 0.5 & $\begin{array}{l}\text { moist, slanted bottom due to non-square cutting of tube; bottom slice surface from } 6 \text { to } 6.5 \text { in. Sliced } \\
\text { core to give flat surface. }\end{array}$ \\
\hline 708 & 14 & 6.5 to 9.875 & 6 & 6.5 & 0.5 & \\
\hline 709 & 15 & 6.5 to 9.875 & 6.5 & 7 & 0.5 & $\begin{array}{l}\text { Filter located at } 7 \text { inches. Filter largely in tack and was in } 1 \text { piece. } 2 \text { or } 3 \text { pieces attached to soil that } \\
\text { accounted for }<3 \% \text { of filter. Removed filter from soil sample. }\end{array}$ \\
\hline 710 & 16 & 6.5 to 9.875 & 7 & 7.5 & 0.5 & Filter located at 7 in. See note above. \\
\hline 711 & 17 & 6.5 to 9.875 & 7.5 & 8 & 0.5 & \\
\hline 712 & 18 & 6.5 to 9.875 & 8 & 8.5 & 0.5 & \\
\hline 713 & 19 & 6.5 to 9.875 & 8.5 & 9 & 0.5 & \\
\hline 714 & 20 & 6.5 to 9.875 & 9 & 9.5 & 0.5 & \\
\hline 715 & 21 & 6.5 to 9.875 & 9.5 & 9.875 & 0.375 & \\
\hline 716 & 22 & 6.5 to 9.875 & 9.875 & 10.875 & 1 & \\
\hline 717 & 5 & 9.875 to 17.375 & 10.875 & 11.875 & 1 & \\
\hline 718 & 4 & 9.875 to 17.375 & 11.875 & 12.875 & 1 & \\
\hline 719 & 3 & 9.875 to 17.375 & 12.875 & 13.875 & 1 & $\begin{array}{l}\text { Dry. This sample totally crumbled \& fell out of core. Slice top \& bottom were estimated based on } \\
\text { measurements from top \& bottom of core. Contained } 1 \text { in rock; threw away. }\end{array}$ \\
\hline 720 & 2 & 9.875 to 17.375 & 13.875 & 16 & 2.125 & Dry. Large portion of sample was not collected because it got contaminated with other sample. \\
\hline 721 & 1 & 9.875 to 17.375 & 16 & 16.625 & 0.625 & \\
\hline 722 & 0.5 & 9.875 to 17.375 & 16.625 & 17.375 & 0.75 & $\begin{array}{l}\text { Dry. Top of core actually sloped from } 16.25 \text { to } 17.75 \text {. After this slice was removed, the core was } \\
\text { flat. }\end{array}$ \\
\hline 723 & & & Filter** & & & Submit $1 / 4$ the filter to ADS for analysis. Taken from 6.5 to 9.875 inches. \\
\hline 724 & & & Background & & & Sediment from: "Control" M-11 Minilysimeter \\
\hline
\end{tabular}

** $\quad$ Filter: The filter had a shape of a flattened circle with one dimension of 1 inch and a second dimension of 0.875 inches. The filter was cut in 4 equal parts. One section was submitted for total analysis. When the filter was cut, it broke apart, showing the 2 individual filters used to sandwich the $\mathrm{Pu}\left(\mathrm{C}_{2} \mathrm{H}_{4}\right)_{2}$. An army green color circle could be seen in the middle of both filter papers; it form a circle with a diameter of $\sim 1-\mathrm{cm}(3 / 8 \mathrm{inch})$. This color is likely not the $\mathrm{Pu}\left(\mathrm{C}_{2} \mathrm{H}_{4}\right)_{2}$, but instead is algae that fed on the $\mathrm{C}_{2} \mathrm{H}_{4} . \mathrm{Pu}(\mathrm{IV})$ is typically blue, whereas $\mathrm{Pu}(\mathrm{III})$ is green. Furthermore, you need $\sim 0.1 \mathrm{Ci} \mathrm{Pu}-239$ to see any color. The filter received only about $0.0005 \mathrm{Ci} \mathrm{Pu}-239$. 


\subsection{MATERIALS AND METHODS FOR RECOVERING DEPTH-DISCRETE SAMPLES FROM THE MINI-LYSIMETER SEDIMENT M-12 CORE CONTAINING PU ${ }^{\text {III }} \mathbf{C L}_{3}$}

1. Conduct of Operations' R\&D Hazards Screening Checklist is located in lab notebook: wsrcnb-2003-00251, page 5.

2. Record all notes on column label into lab notebook.

3. Tamped sediment in column so that sediment is compacted at the bottom.

4. Measured total length of sediment column: 15.625 inches.

5. Cut column 7 and 14 inches from bottom.

6. Extruded sediment using ELE International Sample Ejector in $1 / 2$ - and 1-inch sections in the order shown in Table 1. Sample ID\# 1220, $14-15.625$ inches from bottom, will be collected by digging out sediment from the $14-30$ inch section of tube.

7. Place sediment in plastic weighing boats and then place the sediment-holding weighing boats in zip-locked bags.

8. Submitted $\sim 3$-g air-dried sample to ADS for

- Sodium-Peroxide Fusion Digestion and Nitric Acid Uptake

- $\mathrm{Pu}-239 / \mathrm{Pu}-238$ concentrations of total digestion (Check with Dave Diprete). 
WSRC-TR-2004-00493, REV. 0

Table 1. Sample Collection Order and Description $(0$ inches $=$ bottom of core, 17 inches $=$ top of core $)$.

\begin{tabular}{|c|c|c|c|c|c|c|c|}
\hline & & Casing & Targetted & Actual & Actual & Actual & Observations \\
\hline Original ID & $\begin{array}{l}\text { Sampling } \\
\text { Sequence }\end{array}$ & $\begin{array}{l}\text { Height } \\
\text { Casing \# }\end{array}$ & $\begin{array}{l}\text { Sample Height } \\
\text { (inches) }\end{array}$ & $\begin{array}{l}\text { Sample Thickness } \\
\text { (inches) }\end{array}$ & $\begin{array}{c}\text { Bottom of Sample } \\
\text { (inches) }\end{array}$ & $\begin{array}{l}\text { Top of Sample } \\
\text { (inches) }\end{array}$ & \\
\hline 1219 & & $14-30$ & $15.625-17.0$ & (minc) & 15.625 & (IIticis) & $\begin{array}{l}\sim 140 \mathrm{~mL} \text { of dry sediment laid loose in the tube, separate from the } \\
\text { moist sediment core. It was collected in this sample and estimated } \\
\text { to be } \sim 1.375 \text { inches thick. Inner diameter of core casing }=2.813 \\
\text { inches }\end{array}$ \\
\hline 1220 & 2 & $14-30$ & $14-15.625$ & 1.625 & 14 & 15.625 & \\
\hline 1232 & 3 & $7-14$ & $12.5-14$ & 0.875 & 13.125 & 14 & \\
\hline 1233 & 4 & $7-14$ & $11.5-12.5$ & 0.875 & 12.25 & 13.125 & \\
\hline 1234 & 5 & $7-14$ & $10.5-11.5$ & 0.875 & 11.375 & 12.25 & \\
\hline 1235 & 6 & $7-14$ & $9.5-10.5$ & 0.875 & 10.5 & 11.375 & \\
\hline 1236 & 7 & $7-14$ & $8.5-9.5$ & 0.875 & 9.625 & 10.5 & \\
\hline 1237 & 8 & $7-14$ & $8-8.5$ & 0.5 & 9.125 & 9.625 & \\
\hline 1238 & 9 & $7-14$ & $7.5-8$ & 0.5 & 8.625 & 9.125 & \\
\hline 1239 & 10 & $7-14$ & $7-7.5$ & 0.875 & 7.75 & 8.625 & \\
\hline $1239 \mathrm{~b}$ & 11 & $7-14$ & added sample & 0.5 & 7.25 & 7.75 & $\begin{array}{l}\text { Filter located at } 7.25 \text { inches from bottom (at interface between } \\
\text { samples } 1239 \mathrm{~b} \& 1239 \mathrm{c}){ }^{(2)}\end{array}$ \\
\hline $1239 \mathrm{c}$ & 12 & $7-14$ & added sample & 0.25 & 7 & 7.25 & $\begin{array}{l}\text { A clump of sediment in contact with the filter was removed from } \\
\text { this sample to do XAS. This will lower the measured Pu } \\
\text { concentration in this sample. }\end{array}$ \\
\hline 1221 & 13 & $0-7$ & $0-1$ & 1.25 & 0 & 1.25 & $\begin{array}{l}\text { Had difficulty pushing sediment through the } 0-7 \text { in casing. Ended } \\
\text { up squeezing out water. Definitely compressed sample during } \\
\text { sampling. The sample was compressed } \sim 0.5 \text { in from the } 7 \text { in core. } \\
\text { This } 0.5 \text { inches was evenly distributed between Samples } 1221-1229 \text {. } \\
\text { The liquid was acidified \& sent off for total Pu analysis. }\end{array}$ \\
\hline 1222 & 14 & $0-7$ & $1-2$ & 1.125 & 1.25 & 2.375 & \\
\hline 1223 & 15 & $0-7$ & $2-3$ & 1 & 2.375 & 3.375 & \\
\hline 1224 & 16 & $0-7$ & $3-4$ & 1 & 3.375 & 4.375 & \\
\hline 1225 & 17 & $0-7$ & $4-4.5$ & 0.5 & 4.375 & 4.875 & \\
\hline 1226 & 18 & $0-7$ & $4.5-5$ & 0.5 & 4.875 & 5.375 & \\
\hline 1227 & 19 & $0-7$ & $5-5.5$ & 0.5 & 5.375 & 5.875 & \\
\hline 1228 & 20 & $0-7$ & $5.5-6$ & 0.5 & 5.875 & 6.375 & \\
\hline 1229 & 21 & $0-7$ & $6-6.5$ & 0.625 & 6.375 & 7 & \\
\hline 1230 & Control & & & & & & Sample from control lysimeter M-8, that did not receive any $\mathrm{Pu}$. \\
\hline 1231 & $1 / 4$ filter & & & & & & $1 / 4$ of entire filter was sent off for analysis. \\
\hline
\end{tabular}

Notes: 1. Collected 2 petri dishes. One contains filter. Second contains sediment immediately below and in contact with filter (from sample \#1239c; 7 - 7.25 in).

2. Entire filter was collected. It had a 1 inch diameter.

3. All sediment samples were moist, except 1219 .

4. Prior to cutting the core open, it was predicted that the filter holding the $\mathrm{PuCl}_{3}$ was located 5.75 inches from the bottom because Core $\mathrm{M}-9$, $\mathrm{Pu}$ (V) $\left(\mathrm{NO}_{3}\right)_{4}$, also consisted of a 15.625 -inch sediment core and its filter was located at the height above the core bottom. Ordered the sample collection to minimize smearing Pu upward, that is, smearing Pu towards the top of the core. 
WSRC-TR-2004-00493, REV. 0

\subsection{MATERIALS AND METHODS FOR PREPARING NATIONAL SYNCHROTRON LIGHT SOURCE SAMPLES}

Objective: Preparing sample mounts from the Pu lysimeters to be analyzed off-site at the National Synchrotron Light Source located at Brookhaven National Laboratory. For practice, we will prepare some non-rad sample mounts. Once we develop the necessary techniques and Martine agrees they are $\mathrm{OK}$, we will prepare the actual rad mounts.

\section{Reminder:}

- $\quad$ Lysimeter $\mathrm{M}-9$ contained $\mathrm{Pu}\left(\mathrm{NO}_{3}\right)_{4}$

- Lysimeter $\mathrm{M}-12$ contained $\mathrm{PuCl}_{3}$

- Lysimeter $\mathrm{M}-7$ contained $\mathrm{Pu}\left(\mathrm{C}_{2} \mathrm{H}_{4}\right)_{2}$

\section{Materials:}

1. 6 sample holders (2 extra) (from Martine)

2. 6 1-inch round glass slides (from Martine)

3. kapton tape (from Martine)

4. Super glue (order)

5. Filter from M-9 (the entire recovered filter was submitted to ADS for total Pu activity analysis. We will use filter still stuck to clogs of soil separated from other samples and stored in jar. - Sample ID\#1

6. Filter from M-12 - Sample ID\#2

7. Filter from M-7 - Sample ID\#9

8. Sediment from as close as possible to M-9 filter. I believe we had a separate baggie that held soil + filter; it is from this baggie that we want to sample from. - Sample ID\#3

9. Sediment from the aggregate we saved in the Petri dish that was in contact with M-12 filter-Sample ID\#4

10. Sediment from as close as possible to M-7 filter. The filter was separated from the sediment in baggie \#710. Although, I believe we had a separate baggie that held soil + filter; it is from this baggie that we want to sample from. - Sample ID\#10

11. When we prepared samples for SEM analysis, we collected $<2-\mu \mathrm{m}$ (clay) fraction for sample \#227 (6.125 - 6.375 inch height) from M-9. We need a couple particles from this for Sample ID\#5.

12. When we prepared samples for SEM analysis, we collected $<2-\mu \mathrm{m}$ (clay) fraction for sample \#228 (5.625 - 6.125 inch height) from M-9. We need a couple particles from this for Sample ID\#6.

13. Sediment \#223 (3 - 4 inch height) from M-9 - Sample ID\#7.

14. Sediment \#225 (4.5 - 5 inch height) from M-9 - Sample ID\#8.

15. Sediment from the control lysimeters (M-9) for practicing making slide mounts.

16. Practice, non-rad filter for practicing making slide mounts.

17. $25 \mathrm{~g} / 0.5 \mathrm{~L}$ Hexametaphosphate (HMP) Stock Solution

18. 10\% HMP Solution: Bring 200mL HPM Stock Solution up to 2-L with water

19. 270-mesh $(53 \mu \mathrm{m})$ sieve 


\section{Methods:}

1. The R\&D Hazards Screening Checklist is located in WSRC-NB-203-00251 on page 23.

2. Cathy, I will work closely with you in the lab to develop laboratory techniques to mount these samples. Do steps $3-8$ on lab bench top; this is non-rad work.

3. Cut a practice, non-rad filters into $\sim 1 / 8 \times 1 / 8$ inch square; precise size is not important.

4. Add Super Glue to $\sim 1 / 4$ inch diameter area on a glass circular slide.

5. Quickly place 1/8 inch filter on Super Glue spot. Make sure filter is flat, no air pockets.

6. Add Super Glue to $\sim 1 / 4$ inch diameter area on another glass circular slide.

7. Add control (non-rad) sediment and/or clay sample to glue area in a tightly packed, 2dimensional manner, i.e., flat.

8. Let glue dry. Place a small piece of special kapton tape over sample.

9. Ask Connie to carefully smear the tape (or at least look at the sample and think about how she will eventually smear these samples). I would like her to get practice smearing this tiny sample; she will need to be careful not to destroy our sample.

10. Once we develop our technique we will try to put the 10 samples on 4 sample holders (4 slides). We may need to use more slide holders. We'll see.

\section{Clay Separation from Bulk Sediment}

11. Sample ID\#7 \& \#8 need to be prepared. The clay-size fractions of these two sediments need to be collected as follows.

12. Pass $15 \mathrm{~g}$ of both sediments through the 270 -mesh sieve (53- $\mu \mathrm{m}$ opening). Wipe sieve very well with a slightly moist Kimwip and then a dry Kimwip between the two samples. Be sure to dry very well between uses.

13. Add $230 \mathrm{~mL}$ of $10 \%$ HPM Solution to a $250-\mathrm{mL}$ large-mouth Nalgene bottle. Transfer the $<53 \mu \mathrm{m}$ clay/silt fraction into solution. Put on rotating shaker overnight.

14. Shake vigorously by hand for 1 minute. Mark top of water line and $5.9 \mathrm{~cm}$ below water line with a Sharpie. Loosen top and set in hood for 4.5 hours. Siphon suspension from the top $5.9 \mathrm{~cm}$ and save clay suspension. (Let me know if you need help with this step.)

15. Bring volume back up to $230 \mathrm{~mL}$ with $10 \%$ HMP Solution.

16. Repeat steps $13 \& 14$. Combine clay suspensions from the same sediment sample.

17. Collect $<2 \mu \mathrm{m}$ particles. They need to be air dried for mounting on slide. 
WSRC-TR-2004-00493, REV. 0

This page has been left purposely blank. 
WSRC-TR-2004-00493, REV. 0

\subsection{APPENDIX B: ADDITIONAL MICRO-XRF ELEMENTAL MAPS}



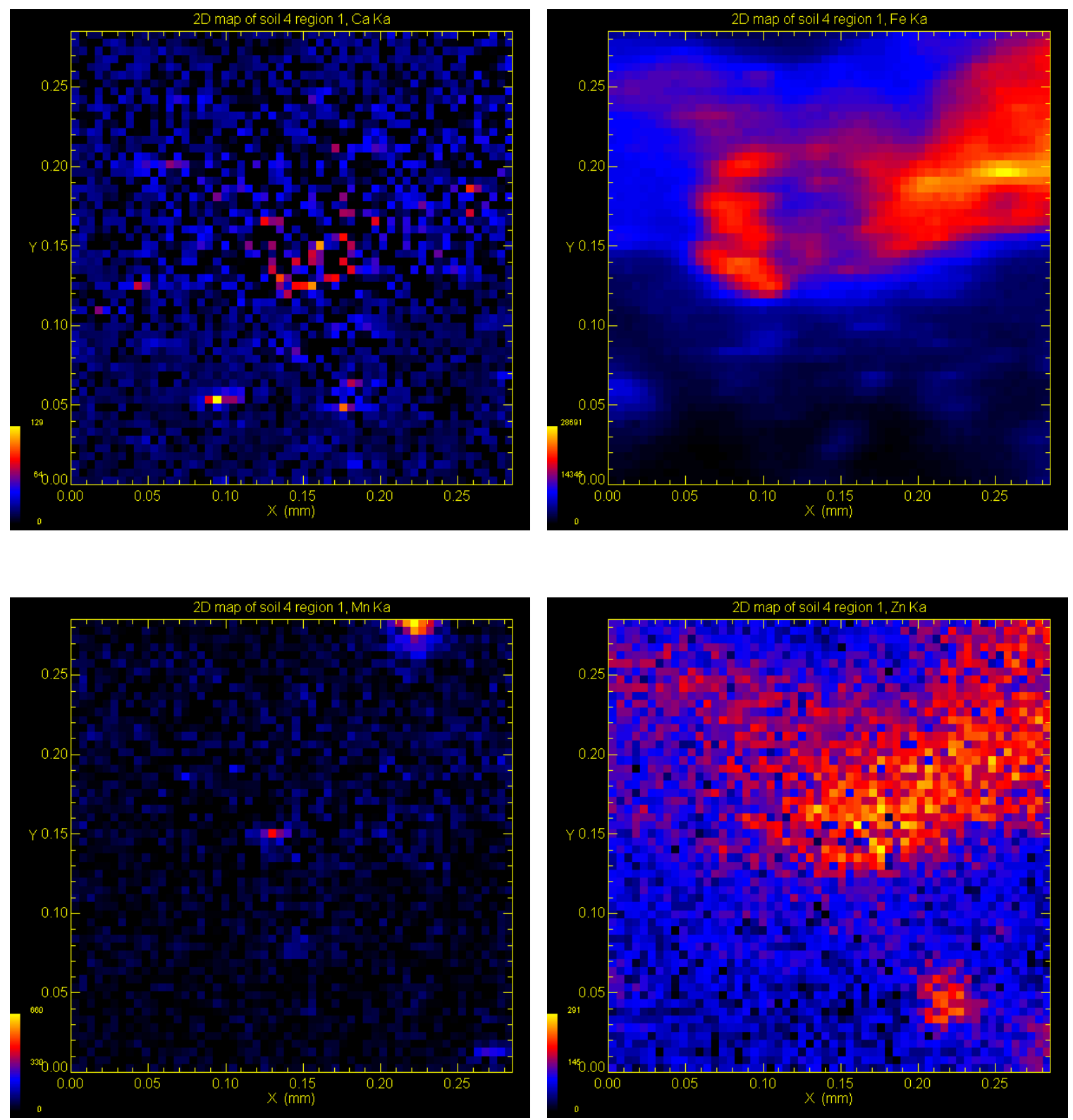

Figure A 1. Micro-SXRF elemental map images of sediment next to the $\mathrm{Pu}(\mathrm{III})$-spiked filter in $\mathrm{PuCl}_{3}$ lysimeter (Sample \#4): (top left) calcium, (top right) iron, (bottom left) manganese, and (bottom right) zinc. Figure A1 includes maps of other elements from the same sample location. Figure A2 includes maps of other elements from the same sample location. 
WSRC-TR-2004-00493, REV. 0
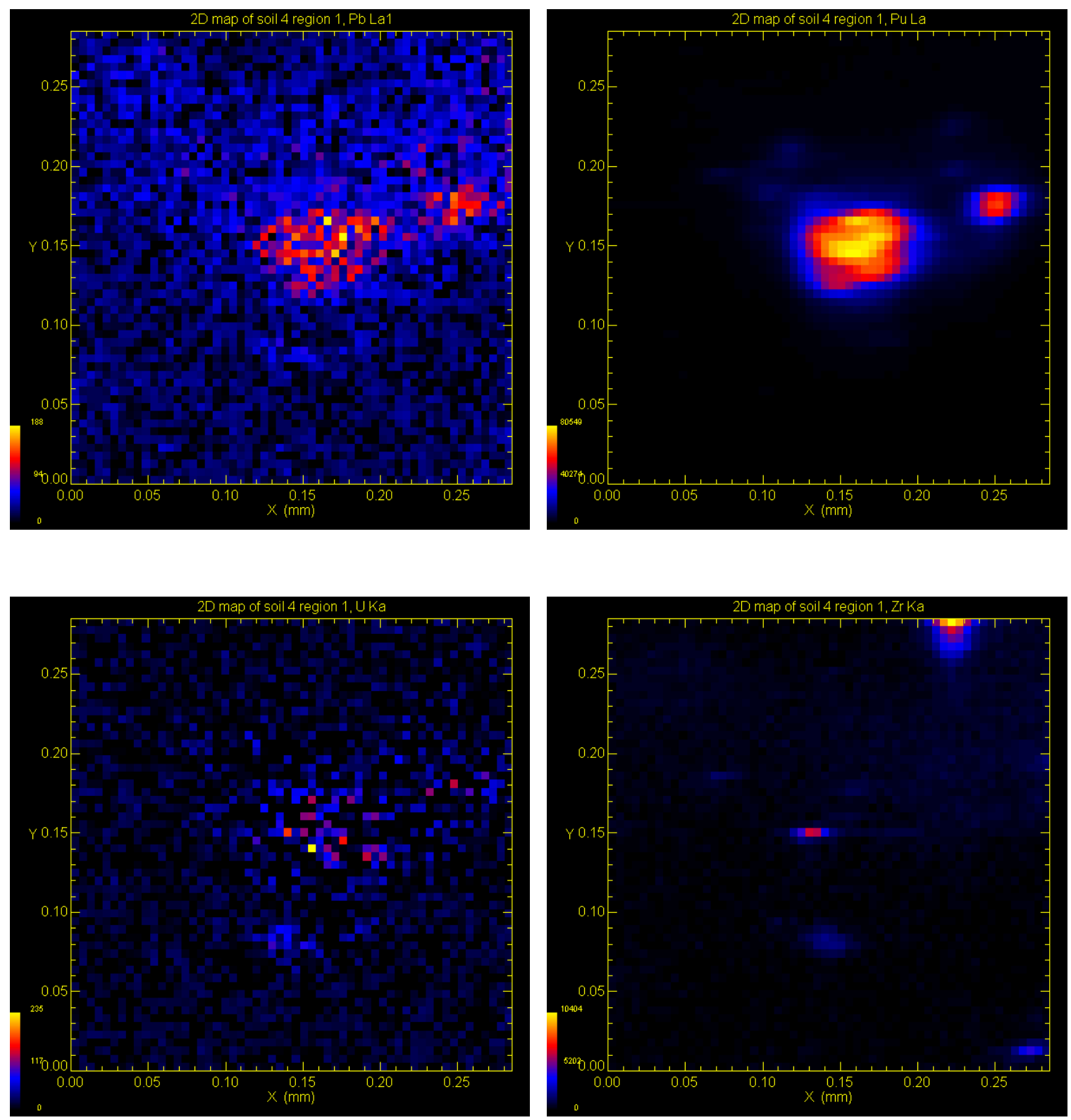

Figure A 2. Micro-SXRF elemental map images of sediment next to the $\mathrm{Pu}(\mathrm{III})$-spiked filter in $\mathrm{PuCl}_{3}$ lysimeter (Sample \#4): (top left) lead, (top right) plutonium, (bottom left) uranium, and (bottom right) zirconium. This soil sample was taken from the region where the $\mathrm{Pu}(\mathrm{III})$-spiked filter was in contact with the sediment. Figure A1 includes maps of other elements from the same sample location. 
WSRC-TR-2004-00493, REV. 0
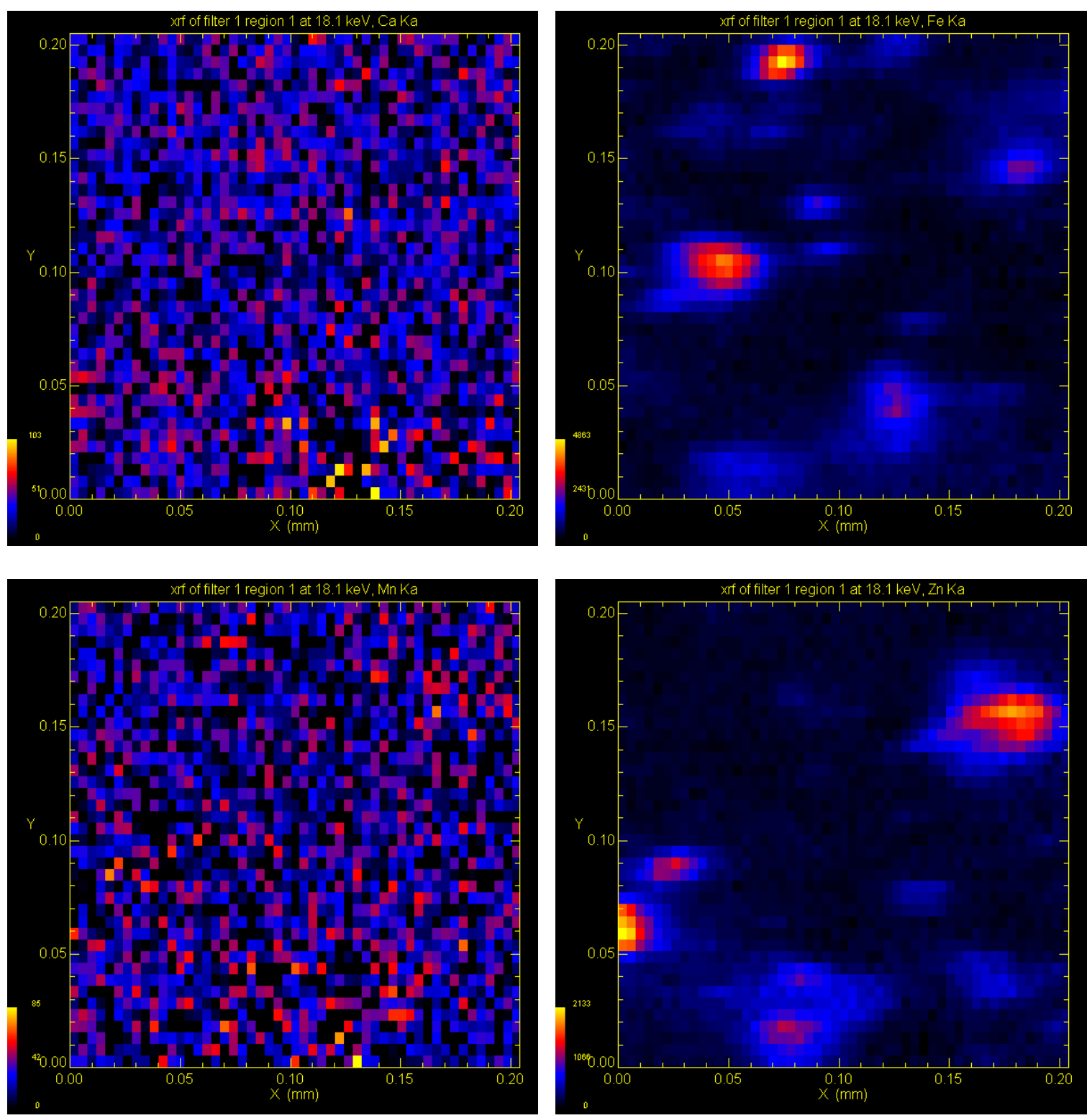

Figure A 3. Micro-SXRF elemental map images of sediment next to the Pu(IV)-spiked filter in $\mathrm{Pu}\left(\mathrm{NO}_{3}\right)_{4}$ lysimeter: (top left) calcium, (top right) iron, (bottom left) manganese, and (bottom right) zinc. Figure A4 include maps of other elements from the same sample location. 
WSRC-TR-2004-00493, REV. 0
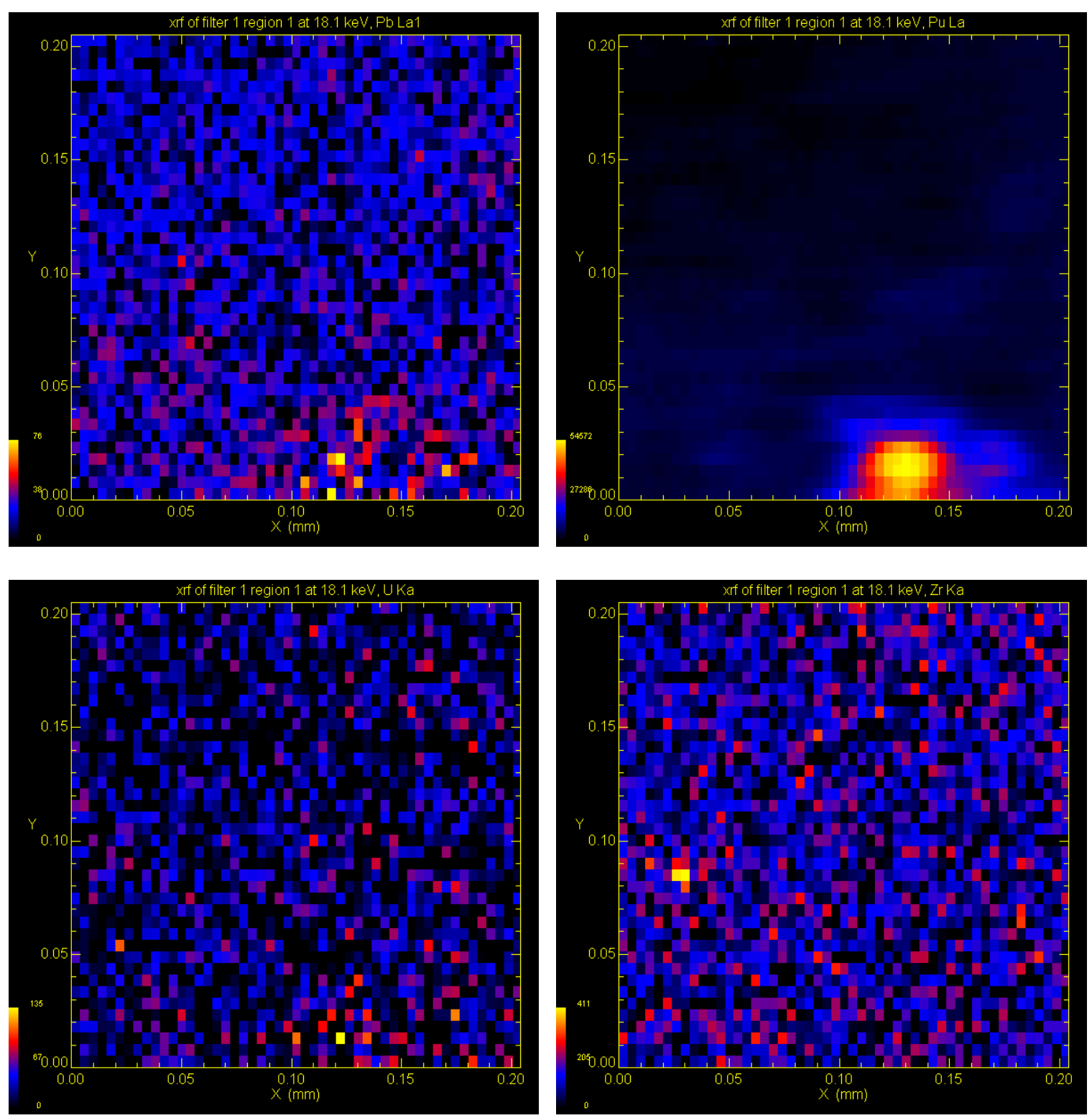

Figure A 4. Micro-SXRF elemental map images of sediment next to the $\mathrm{Pu}(\mathrm{IV})$-spiked filter in $\mathrm{Pu}\left(\mathrm{NO}_{3}\right)_{4}$ lysimeter: (top left) lead, (top right) plutonium, (bottom left) uranium, and (bottom right) zirconium. Figure A3 includes maps of other elements from the same sample location. 